\title{
Pharmacology of natural radioprotectors
}

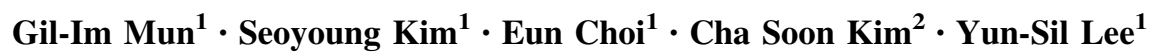

Received: 15 April 2018/Accepted: 12 October 2018/Published online: 25 October 2018

(C) The Author(s) 2018

\begin{abstract}
Radiotherapy is one of the most efficient ways to treat cancer. However, deleterious effects, such as acute and chronic toxicities that reduce the quality of life, may result. Naturally occurring compounds have been shown to be non-toxic over wide dose ranges and are inexpensive and effective. Additionally, pharmacological strategies have been developed that use radioprotectors to inhibit radiation-induced toxicities. Currently available radioprotectors have several limitations, including toxicity. In this review, we present the mechanisms of proven radioprotectors, ranging from free radical scavenging (the bestknown mechanism of radioprotection) to molecular-based radioprotection (e.g., upregulating expression of heat shock proteins). Finally, we discuss naturally occurring compounds with radioprotective properties in the context of these mechanisms.
\end{abstract}

Keywords Natural compounds · Toxicity · Mechanisms · Radioprotectors

Gil-Im Mun and Seoyoung Kim have contributed equally to this work.

\footnotetext{
Cha Soon Kim

chasoon.kim@khnp.co.kr

$\bowtie$ Yun-Sil Lee

yslee0425@ewha.ac.kr

1 Graduate School of Pharmaceutical Sciences, Ewha Womans University, Seoul 120-750, Korea

2 Radiation Health Institute, Korea Hydro \& Nuclear Power CO., LTD, 172, Dolmr-ro, Seongnam-si, Gyeonggi-do 13605, Korea
}

\section{Introduction}

Radiation therapy is among the most effective treatment modalities for patients with cancer. About $60 \%$ of all patients with cancer receive ionizing radiation (IR) as part of their therapeutic regimen (Moding et al. 2013). While IR is a powerful tool for destroying cancer cells, it is also toxic to normal cells and causes cellular damage and unwanted side effects. IR affects biological molecules both directly and indirectly. Direct effects are mediated by direct interaction of IR with individual DNA moieties, and indirect effects occur via reactive oxygen species (ROS) produced from the molecules surrounding DNA (Wang et al. 2018). Because biological systems contain $75-90 \%$ water, the indirect effect arises from reaction of water radiolysis products ( $\mathrm{OH}$ : hydroxyl radicals, solvated electrons, and hydrogen atoms) with DNA. The hydroxyl radical is highly reactive, has powerful oxidizing effects, and can diffuse to react with all cell constituents (Fig. 1). DNA, lipids, and proteins are the main attack targets for hydroxyl radicals. Release of damage-associated molecules and cytokines or chemokines in response to the DNA damage, ROS generation, and apoptosis caused by IR activate the immune system and cause inflammation. This immune activation results in an acute inflammatory phase that is characterized by an enhanced pro-inflammatory response. Inflammation and repair induction after IR are paralleled by mitotic cell death and the subsequent release of cytokines and growth factors, which result in the chronic phase of IR damage (Wirsdorfer and Jendrossek 2016). Many diseases are associated with IR responses, including those caused by acute phase damage (organ inflammation) or chronic phase damage (fibrosis, atrophy, vascular damage, infertility, and secondary malignancies) (Fig. 2). 


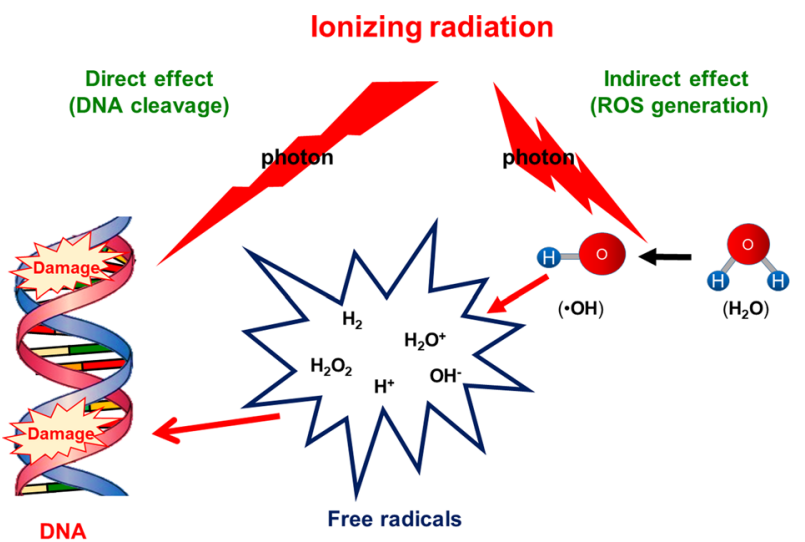

Fig. 1 Direct and indirect actions of radiation (modified from Wang et al. 2018). Direct action is mediated by interaction of a secondary electron, resulting from absorption of an X-ray photon, with the DNA. Indirect action is mediated by interaction of a secondary electron with a water molecule to produce reactive oxygen species (ROS), which induces DNA damage

There is considerable interest in protecting normal cells from IR. In addition to technological improvements in IR delivery and accuracy, pharmacological agents are being used as an alternative to decrease toxicity to normal tissues. The IR research program of the National Cancer Institute proposed the following pharmacological classification of agents with IR protection properties according to timing of administration: (a) protection, (b) mitigation, and (c) therapeutic agents (Citrin et al. 2010). An ideal radioprotective agent should prevent direct acute or chronic effects on normal tissue, be easily dispensed without toxicity, and not protect tumors from IR. Radioprotectors are used as a prophylactic strategy against chemical effects according to the classification timescale proposed. They are administered before radiotherapy or IR exposure to prevent the occurrence of either acute or chronic effects. Mitigators reduce the IR effects on normal tissues before emergence of symptoms and are administered during or shortly after radiation therapy or IR exposure. Lastly, therapeutic agents are used for treatment following IR to reduce deleterious or chronic effects and are administered after symptoms have presented (Bourgier et al. 2012). Therapeutic agents were initially developed in case of accidental IR exposure and were later adapted to treat acute or chronic effects following IR treatment (Fig. 3). A number of compounds have been studied for potential as radioprotectors, mitigators, and therapeutic agents, and the compounds currently approved by the U.S. Food and Drug Administration (FDA) or in the FDA-Investigational New Drug (IND) application process are described in Table 1.
Fig. 2 Acute and late effects of radiation exposure (modified from Wirsdorfer and Jendrossek 2016). Radiation effects are commonly divided into acute, or early, and late effects, which are induced after the initial radiation responses. They demonstrate different response patterns to radiation doses. Acute effects result from death of a large number of cells in tissue with rapid rates of turnover and occur within days to weeks of irradiation. Late effects occur months to years after irradiation in tissues with slow cell turnover and usually are persistent and progressive. dsDNA double strand DNA, ssDNA single strand DNA, ROS reactive oxygen species, $R N S$ reactive nitrogen species

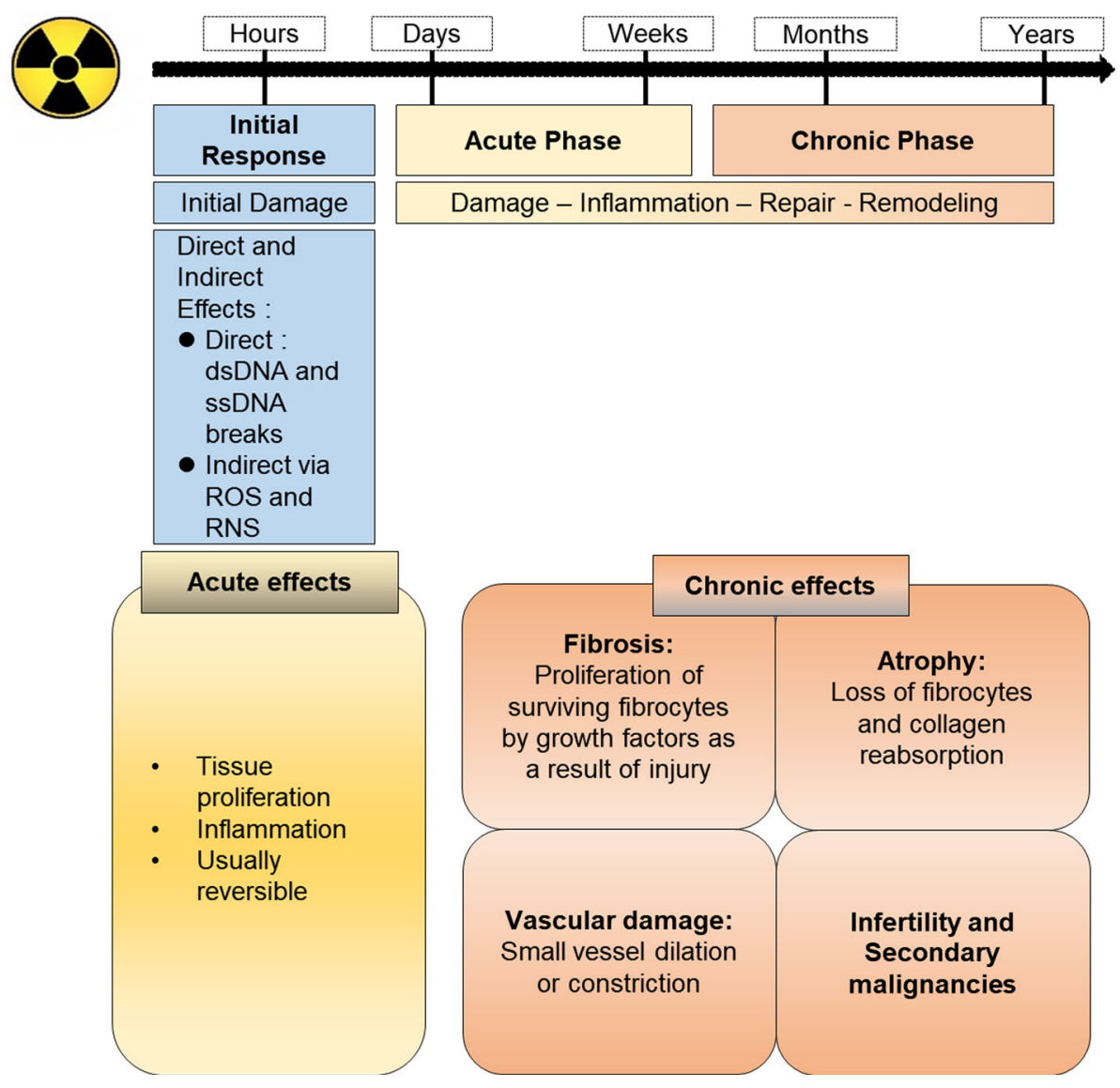


Fig. 3 Pharmacological classification of agents with radiation protection properties (modified from Bourgier et al. 2012). Radioprotectors are classified according to when they are administered in relation to radiation and/or its effects. Radioprotectors are administered before radiation exposure to prevent the occurrence of either acute or late effects. Mitigators reduce the action of radiation on normal tissues before radiation emergence syndrome.

Therapeutic agents are administered after radiation exposure to treat late effects
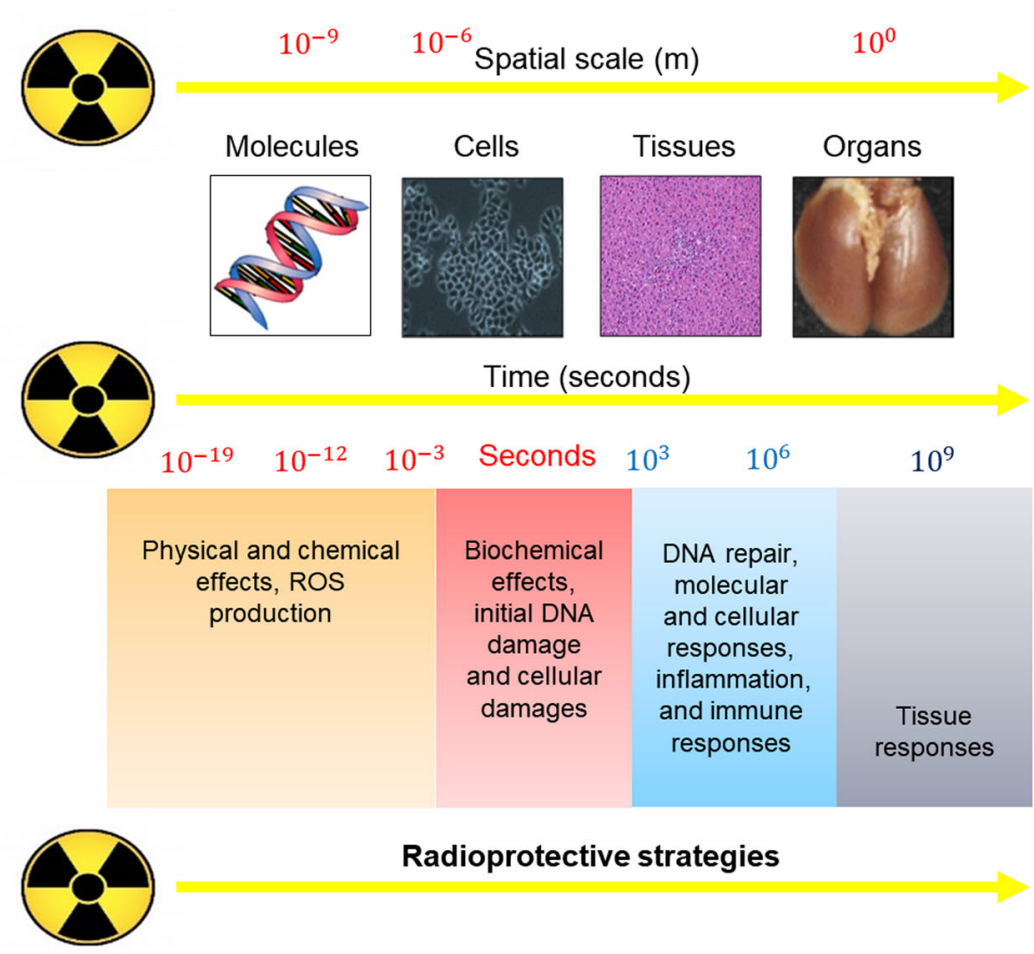

Radioprotective strategies

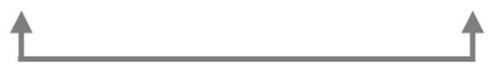

Mitigation
Therapeutic
Over the last few decades, many natural and synthetic compounds have been investigated for their potential as radioprotectors. However, amifostine, developed by the U.S. Army Anti-Radiation Drug Development Program, is the only chemical radioprotector currently approved by the FDA. Amifostine has disadvantages such as limited administration routes, narrow administration window for efficacy, high cost, and limited protection of organs (Cheki et al. 2016). Thus, while chemical radioprotectors remain a subject of active research, their efficacy is often limited by high toxicity, side effects, and high cost. Due to the inherent toxicity of synthetic chemicals, an interest in natural plants and phytochemicals as a potential source of radioprotectors has developed. Naturally occurring compounds with discrete bio-activities are being widely examined for their potential ability to provide health benefits, and a number of naturally occurring compounds have demonstrated radioprotective activities. Since naturally occurring compounds are typically less toxic than synthetic compounds and can be less expensive, they are preferable sources of radioprotectors. Therefore, screening of naturally occurring compounds is a major focus for new drug discovery. This review evaluates the radioprotective effects of naturally occurring compounds and the mechanisms underlying these effects (Table 2; Figs. 4, 5).

\section{Underlying mechanisms of radioprotectors}

\section{Antioxidation}

During radiation exposure, IR generates free radicals and ROS, which result in cellular damage. Free radicals induce DNA damage by introducing base damage, DNA doublestrand breaks (DSBs), and DNA-DNA or DNA-protein cross-links. These effects can alter gene expression and cause protein modifications, cell death, senescence, and genomic instability. Exposure of cells to a typical clinical dose of IR has been shown to result in an average of 1000 DNA single-strand breaks (SSB), 40 DNA DSBs, and 3000 damaged bases per Gray (Gy) (Hall and Giaccia 2012). Since most of this IR damage arises from interaction of IRinduced free radicals with biomolecules, agents that can destroy free radicals or prevent formation of free radicals can inhibit these reactions and function as radioprotectors. Free radicals are short-lived and interact rapidly with biomolecules (Lobo et al. 2010). Therefore, to provide proper radioprotection, effective molecules need to be present in the cellular systems at a sufficient concentration at the time of IR exposure. 
Table 1 FDA approved- or IND application drugs for radioprotectors, mitigators, and therapeutic agents

\begin{tabular}{|c|c|c|c|c|}
\hline Categories & $\begin{array}{l}\text { Generic name (chemical names and } \\
\text { pharmaceutical labels) }\end{array}$ & Specific use & $\begin{array}{l}\text { FDA } \\
\text { status }\end{array}$ & References \\
\hline $\begin{array}{r}\text { Nutraceuticals- } \\
\text { Isoflavonoids }\end{array}$ & $\begin{array}{l}\text { Genistein }\left(4^{\prime} 5,7 \text { trihydroxy- }\right. \\
\left.\text { isoflavonoid; Bio } 300^{\mathrm{TM}}\right)\end{array}$ & $\begin{array}{l}\text { Survival and organ system protection (i.e., } \\
\text { marrow, gut, and lung) }\end{array}$ & IND & $\begin{array}{l}\text { Day et al. } \\
\quad(2008) \\
\text { Landauer et al. } \\
\quad(2003) \\
\text { Zhou and Mi } \\
\quad(2005)\end{array}$ \\
\hline $\begin{array}{l}\text { Immunomodulator- } \\
\text { TLR-5 agonist }\end{array}$ & $\begin{array}{l}\text { CBLB502 (bioengineered truncated } \\
\text { Salmonella sp. flagellin; } \\
\text { Entolimod }^{\mathrm{TM}} \text { ) }\end{array}$ & $\begin{array}{l}\text { Enhancement of survival and protection of } \\
\text { marrow and gut damage in selective animal } \\
\text { models }\end{array}$ & IND & $\begin{array}{l}\text { Burdelya et al. } \\
\text { (2008) } \\
\text { Krivokrysenko } \\
\text { et al. (2012) }\end{array}$ \\
\hline $\begin{array}{l}\text { Cortical steroid } \\
\text { metabolite }\end{array}$ & $\begin{array}{l}\text { 5-AED (androst-5-ene-3 } \beta, 17 \beta \text {-diol; } \\
\text { Neumune }^{\circledR} \text { ) }\end{array}$ & $\begin{array}{l}\text { Enhancement of survival and protection of bone } \\
\text { marrow damage }\end{array}$ & IND & $\begin{array}{l}\text { Stickney et al. } \\
\text { (2007) } \\
\text { Whitnall et al. } \\
\text { (2005) }\end{array}$ \\
\hline Corticosteroid & $\begin{array}{l}\text { BDP/SGX201 (corticosteroid- } \\
\text { beclomethasone } 17,21- \\
\text { dipropionate; OrbeShield }{ }^{\mathrm{TM}} \text { ) }\end{array}$ & $\begin{array}{l}\text { Mitigation of radiation enteritis and promotion of } \\
\text { survival }\end{array}$ & IND & $\begin{array}{l}\text { Singh et al. } \\
\text { (2015) }\end{array}$ \\
\hline $\begin{array}{l}\text { Free-radical } \\
\text { quencher-Meso- } \\
\text { prophyrin mimetic }\end{array}$ & $\begin{array}{l}\text { AEOL } 10150 \text { (Mn prophyrin SOD } \\
\text { mimic) }\end{array}$ & $\begin{array}{l}\text { Mitigation of lung damage; upregulates } \\
\text { antioxidant system }\end{array}$ & IND & $\begin{array}{l}\text { Garofalo et al. } \\
\text { (2014) } \\
\text { Orrell (2006) }\end{array}$ \\
\hline $\begin{array}{l}\text { Recombinant growth } \\
\text { factor }\end{array}$ & rhu G-CSF (filgrastim; Neupogen ${ }^{\circledR}$ ) & $\begin{array}{l}\text { Hemopathological indication; stimulation of } \\
\text { neutrophil production; risk reduction of life- } \\
\text { threatening infections }\end{array}$ & IND & $\begin{array}{l}\text { Farese et al. } \\
\text { (2013) } \\
\text { Gourmelon } \\
\text { et al. (2010) }\end{array}$ \\
\hline $\begin{array}{l}\text { Recombinant } \\
\text { cytokines }\end{array}$ & Rhu IL-12 (HemaMax $\left.{ }^{\mathrm{TM}}\right)$ & $\begin{array}{l}\text { Experimental IND status; enhancement of survival } \\
\text { and protection of marrow and gut damage }\end{array}$ & IND & $\begin{array}{l}\text { Basile et al. } \\
\text { (2012) } \\
\text { Gluzman- } \\
\text { Poltorak et al. } \\
\text { (2014) } \\
\text { Xiong et al. } \\
\text { (2013) }\end{array}$ \\
\hline Binding agents & Prussian Blue (Radiogardase ${ }^{\circledR}$ ) & Chelating agent for Cesium-137 & Approved & Hussar (2005) \\
\hline Blocking agent & $\mathrm{KI}$ & $\begin{array}{l}\text { Thyroid uptake/blocking agent for radio-iodides } \\
\text { (Iodine-131, Iodide-125) }\end{array}$ & Approved & $\begin{array}{l}\text { Hammond } \\
\text { et al. (2007) }\end{array}$ \\
\hline $\begin{array}{l}\text { 5-hydroxy } \\
\text { tryptamine } \\
\text { antagonist }\end{array}$ & Granisetron $\left(\right.$ Kytril $\left.^{\circledR}\right)$ & $\begin{array}{l}\text { Minimizing emetic effects of acute radiation } \\
\text { exposure }\end{array}$ & Approved & $\begin{array}{l}\text { Lanciano et al. } \\
\text { (2001) }\end{array}$ \\
\hline Chemical protectants & $\begin{array}{l}\text { Amifostine/WR2721 (2-(3- } \\
\text { aminopropyl) } \\
\text { aminoethylphosphorothioate; } \\
\left.\text { Ethyol }^{\mathrm{TM}}\right)\end{array}$ & $\begin{array}{l}\text { Cytoprotection (survival protection; systemic } \\
\text { protection of organ systems, but specifically } \\
\text { marrow and gut) }\end{array}$ & Approved & $\begin{array}{l}\text { Culy and } \\
\text { Spencer } \\
(2001) \\
\text { Ormsby et al. } \\
(2014)\end{array}$ \\
\hline $\begin{array}{l}\text { Cytokines and } \\
\text { growth factor }\end{array}$ & Palifermin $\left(\right.$ Kepivance $\left.^{\circledR}\right)$ & $\begin{array}{l}\text { Stimulation of differentiation, proliferation, DNA } \\
\text { repair, and detoxification of ROS }\end{array}$ & Approved & $\begin{array}{l}\text { Finch and } \\
\text { Rubin (2004) }\end{array}$ \\
\hline
\end{tabular}

$T L R$ Toll-like receptor, $A E D$ androstenediol, $S O D$ superoxide dismutase, $B D P$ beclomethasone 17,21-dipropionate, $G$ - $C S F$ granulocyte colony stimulating factor

\section{Anti-inflammation}

IR is indirectly toxic by activating an immune response, and patients undergoing radiation therapy often suffer from widespread inflammation. To improve patient compliance, it is important to relieve the inflammation-associated side effects, and some natural products and their active ingredients can achieve this through anti-inflammatory activity. 
Table 2 List of naturally occurring compounds with radioprotective effects

\begin{tabular}{|c|c|c|c|}
\hline Natural compounds & Source & Radioprotective effects & References \\
\hline Apigenin & Parsley, Celery, Chamomile & Anti-inflammatory, anti-proliferative, and anti-progression & Begum et al. (2012) \\
\hline Bergenin & Caesalpinia digyna & $\begin{array}{l}\text { Activation of the MAP kinase and ERK pathways and protection } \\
\text { against radiation damage }\end{array}$ & $\begin{array}{l}\text { Dwivedi et al. } \\
\text { (2017) } \\
\text { Veerapur et al. } \\
\text { (2009) }\end{array}$ \\
\hline Caffeine & Coffee beans & $\begin{array}{l}\text { Protection against the oxic component of damage in rat liver } \\
\text { mitochondria } \\
\text { Inhibition of radiation-mediated chromosomal aberrations in } \\
\text { mouse bone marrow cells }\end{array}$ & $\begin{array}{l}\text { Hall and Giaccia } \\
\text { (2012) }\end{array}$ \\
\hline $\begin{array}{l}\text { Chlorogenic acid/ } \\
\text { quinic acid }\end{array}$ & $\begin{array}{l}\text { Cinchona bark, Coffee } \\
\text { beans }\end{array}$ & $\begin{array}{l}\text { Anti-inflammation, anti-mutagenic, DNA damage inhibition, and } \\
\text { anti-oxidation }\end{array}$ & $\begin{array}{l}\text { Cinkilic et al. } \\
\text { (2013) }\end{array}$ \\
\hline Coniferyl aldehyde & Eucommia ulmoides & $\begin{array}{l}\text { Induction of heat shock transcription factor } 1 \text { and protection } \\
\text { against radiation damage }\end{array}$ & $\begin{array}{l}\text { Kim et al. (2015) } \\
\text { Nam et al. (2013) }\end{array}$ \\
\hline Curcumin & Turmeric root & $\begin{array}{l}\text { Reduction of gastrointestinal symptoms during chemotherapy and } \\
\text { radiation therapy } \\
\text { Reduction of mucositis during radiation therapy } \\
\text { Reduction of radiation dermatitis and desquamation }\end{array}$ & Verma (2016) \\
\hline Delphinidin & $\begin{array}{l}\text { Carrot, Tomato, Red onion, } \\
\text { Cranberries, Concord } \\
\text { grapes, etc }\end{array}$ & Anti-oxidation and anti-inflammation & $\begin{array}{l}\text { Watson and } \\
\text { Schonlau (2015) } \\
\text { Jeong et al. (2016) }\end{array}$ \\
\hline $\begin{array}{l}\text { Epigallocatechin-3- } \\
\text { gallate }\end{array}$ & Camellia sinensis & $\begin{array}{l}\text { Increased levels of several anti-oxidant enzymes } \\
\text { Protection of skin cells against radiation-induced damage and } \\
\text { radioprotective effects against several radiation-mediated } \\
\text { responses }\end{array}$ & $\begin{array}{l}\text { Zhu et al. (2016) } \\
\text { Zhang et al. (2016) }\end{array}$ \\
\hline Ferulic acid & $\begin{array}{l}\text { Rice, Green tea, Coffee } \\
\text { beans }\end{array}$ & $\begin{array}{l}\text { Protection against radiation-induced damage and enhancement of } \\
\text { DNA repair } \\
\text { Prevention of radiation-induced micronuclei and dicentric } \\
\text { aberrations in human lymphocytes } \\
\text { Enhancement of survival in mice after radiation }\end{array}$ & $\begin{array}{l}\text { Das et al. (2014) } \\
\text { Kikuzaki et al. } \\
\quad(2002) \\
\text { Zhao et al. (2003) }\end{array}$ \\
\hline Genistein & Genista tictoria, etc. & $\begin{array}{l}\text { Protection against acute radiation injury } \\
\text { Multiple mechanisms (e.g., antioxidant, free radical scavenger, } \\
\text { anti-inflammatory, activation of the DNA repair enzyme Gadd } 45\end{array}$ & $\begin{array}{l}\text { Davis et al. (2007) } \\
\text { Grace et al. (2007) } \\
\text { Ahmad et al. } \\
\quad(2010)\end{array}$ \\
\hline Hesperidin & Citrus fruit & $\begin{array}{l}\text { Efficient radioprotection in rat lung tissue } \\
\text { Protection of lipid peroxidation during radiation-induced tissue } \\
\text { damage in rats }\end{array}$ & $\begin{array}{l}\text { Fardid et al. (2016) } \\
\text { Rezaeyan et al. } \\
\quad(2016)\end{array}$ \\
\hline Lycopene & $\begin{array}{l}\text { Tomato, Watermelon, Pink } \\
\text { grapefruit, Papaya, etc }\end{array}$ & $\begin{array}{l}\text { Protection against radiation-induced chromosomal damage in } \\
\text { human lymphocytes } \\
\text { Increased survival after radiation exposure }\end{array}$ & $\begin{array}{l}\text { Kelkel et al. (2011) } \\
\text { Srinivasan et al. } \\
(2009)\end{array}$ \\
\hline $\begin{array}{l}\text { N-Acetyl tryptophan } \\
\text { glucopyranoside } \\
\text { (NATG) }\end{array}$ & Bacillus subtilis & $\begin{array}{l}\text { Overcoming radiation-induced apoptosis by improving } \\
\text { cytoprotective cytokines } \\
\text { Enhancement of antioxidant enzymes against radiation-induced } \\
\text { damage }\end{array}$ & $\begin{array}{l}\text { Malhotra et al. } \\
\text { (2015) } \\
\text { Malhotra et al. } \\
\text { (2018) }\end{array}$ \\
\hline Psoralidin & Psoralea corylifolia & $\begin{array}{l}\text { Inhibition of radiation-induced PI } 3 \text { K-IKK-IкB signaling pathway } \\
\text { and COX-2 expression } \\
\text { Suppression of radiation-induced expression of pro-inflammatory } \\
\text { cytokines }\end{array}$ & $\begin{array}{l}\text { Chiou et al. (2011) } \\
\text { Yang et al. (2011) }\end{array}$ \\
\hline Sesamol & Sesame seeds, Sesame oil & Strong ROS scavenging and antioxidant properties & $\begin{array}{l}\text { Kanimozhi and } \\
\text { Prasad (2009) } \\
\text { Mishra et al. (2011 }\end{array}$ \\
\hline
\end{tabular}


Table 2 continued

\begin{tabular}{|c|c|c|c|}
\hline Natural compounds & Source & Radioprotective effects & References \\
\hline Troxerutin & Sophora japonica & $\begin{array}{l}\text { Protection against radiation-induced damage to the salivary glands } \\
\text { and mucosa } \\
\text { Inhibition of lipid peroxidation in the membranes of subcellular } \\
\text { organelles } \\
\text { Differential protection of normal cells in irradiated tumor-bearing } \\
\text { mice: protection in blood leukocytes and bone marrow cells but } \\
\text { not in tumor cells }\end{array}$ & $\begin{array}{l}\text { Maurya et al. } \\
(2004)\end{array}$ \\
\hline Vanillin & $\begin{array}{l}\text { Vanilla orchid (Vanilla } \\
\text { planifolia, V. fragrans) }\end{array}$ & $\begin{array}{l}\text { Suppression of radiation-induced chromosomal aberrations in cells } \\
\text { and in mice } \\
\text { Anti-mutagenic effects }\end{array}$ & Kumar et al. (2000) \\
\hline Zingerone & Ginger & Anti-oxidation & $\begin{array}{l}\text { Ahmad et al. } \\
\text { (2015) } \\
\text { Rao and Rao } \\
\text { (2010) }\end{array}$ \\
\hline Zymosan A & Saccharomyces cerevisiae & $\begin{array}{l}\text { Protection from radiation-induced apoptosis by upregulating the } \\
\text { levels of cytokines } \\
\text { Protection of cells from radiation-induced DNA damage }\end{array}$ & Du et al. (2018) \\
\hline
\end{tabular}

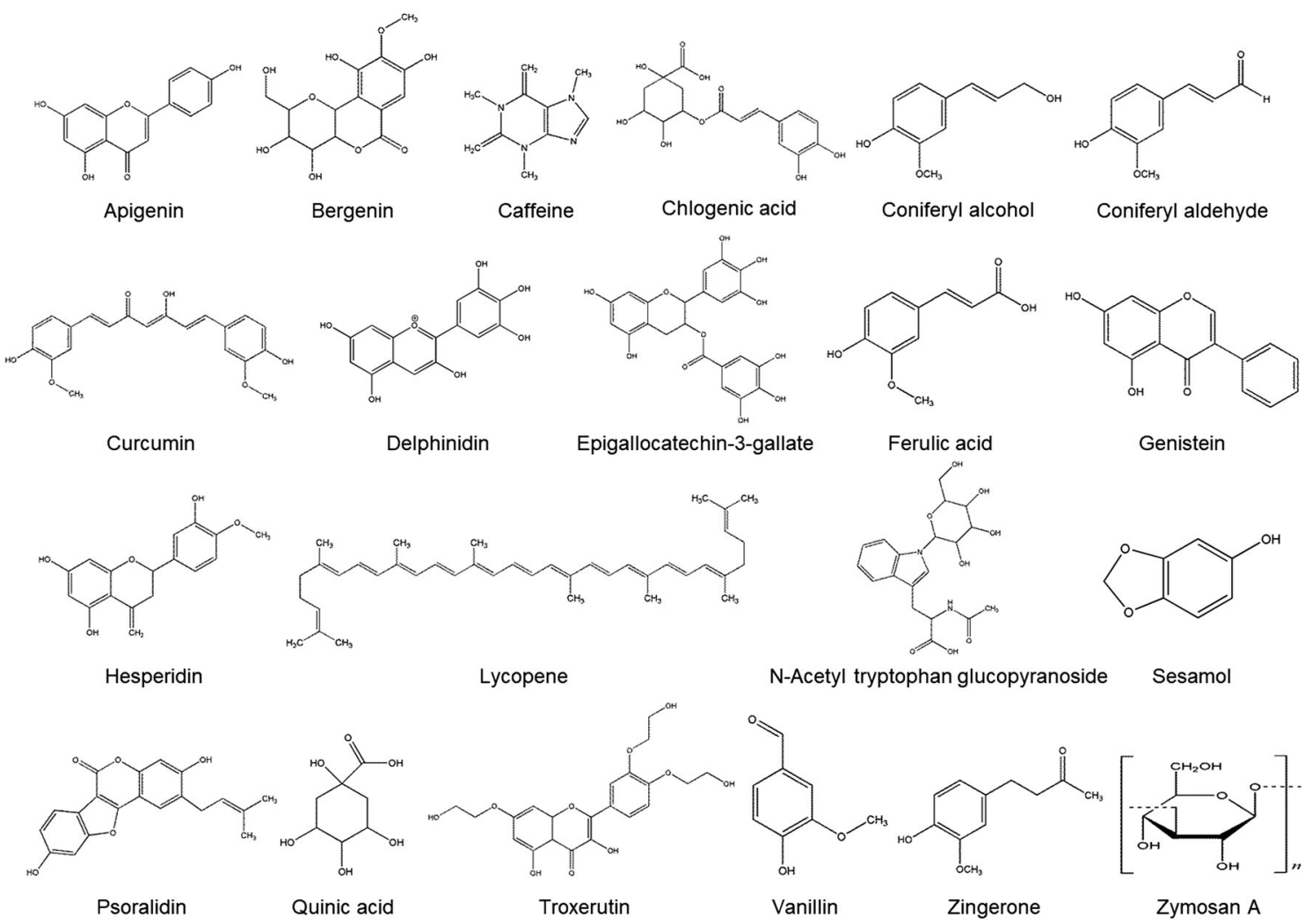

Fig. 4 Chemical structures of naturally occurring compounds with radioprotective effects

After exposure to IR, various pro-inflammatory cytokines and chemokines such as interleukin-1, interleukin-6, tumor necrosis factor $\alpha$, and transforming growth factor $\beta$ (TGF$\beta$ ) are generated (Di Maggio et al. 2015). TGF- $\beta$ is of particular importance in IR damage because this cytokine mediates IR-induced fibrosis of the lungs and skin (Straub et al. 2015). For example, mice fed flaxseed (which is found in Linum usitatissimum) had reduced expression of TGF- $\beta$ and lung injury biomarkers such as Bax and p21, 
Fig. 5 Summary of the cellular mechanisms of naturally occurring compounds with radioprotective effects. Naturally occurring compounds with radioprotective effects occur through different mechanisms, such as free radical scavenging, antiinflammation, facilitation of repair activity, regeneration of hematopoietic cells, and affecting to molecular levels. The mechanisms of radioprotectors are involved in radiation response and tissue damage repair, which may be potential pharmacological targets for development of ideal radioprotectors. $D S B$ double strand break, $S S B$ single strand break, $W B C$ white blood cells, $R B C$ red blood cells

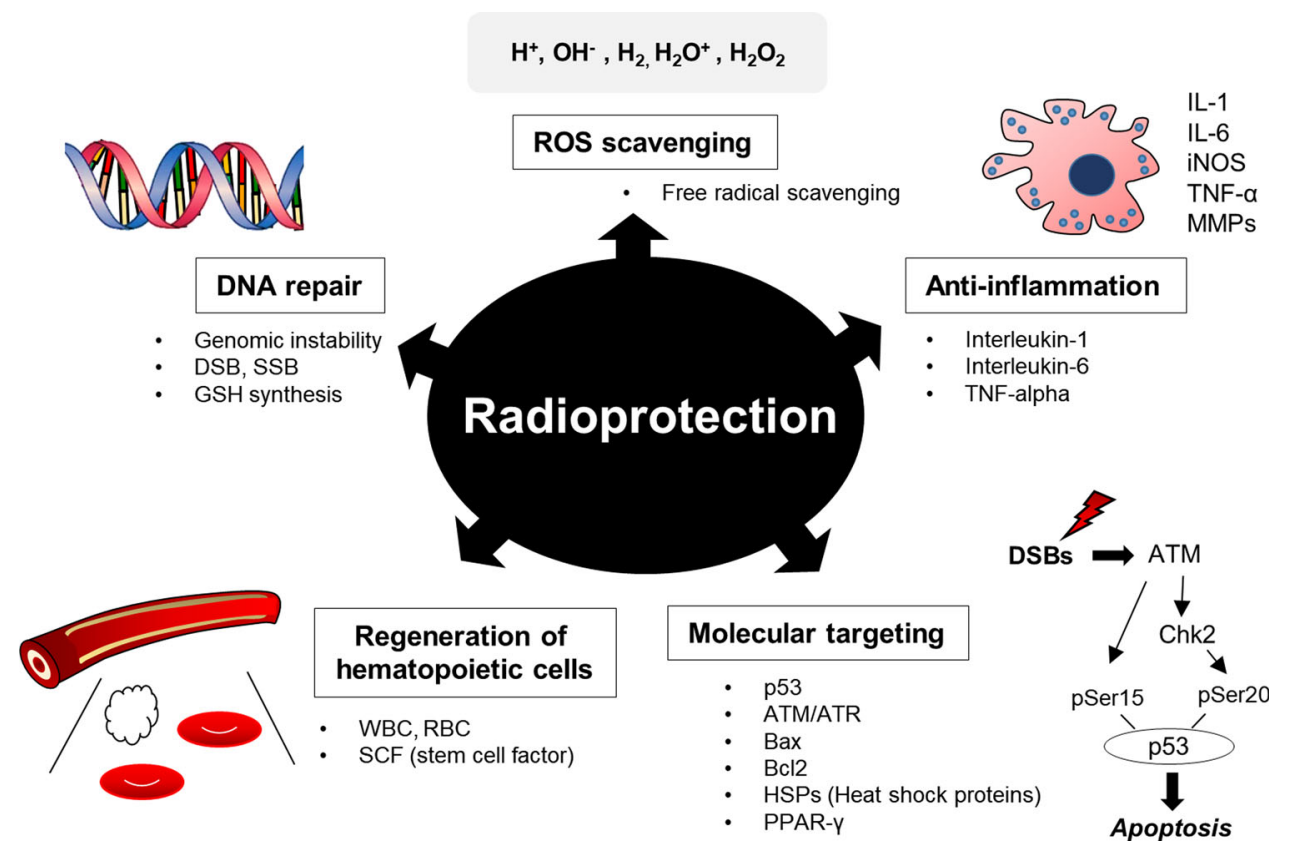

and this was accompanied by reduced lung inflammation and lung fibrosis after radiation therapy (Lee et al. 2009).

\section{DNA repair and cell recovery processes}

Oxidative free radicals can damage DNA by introducing SSB, DSB, and base lesions. While it is important to prevent cellular damage, cellular recovery pathways and repair processes can also mitigate this damage. Several studies have suggested that cellular recovery and repair processes can be enhanced by radioprotectors. Specifically, the DNA SSB repair system is absent in cells deficient in glutathione (GSH) synthesis, suggesting that thiols such as GSH might be involved in the repair of DNA SSB. DNA precursor-synthesizing enzymes such as ribonucleotide reductase also have an important role in DNA repair, and mammalian ribonucleotide reductase activity is induced by DNA damage. Specifically, this enzyme maintains the deoxyribonucleotide concentration, which is important in the excision repair process (Sharygin et al. 2005; Thelander 2007). Overall, higher cellular pools of DNA precursors can create a radioprotective cellular environment, and drugs and chemicals that stimulate the activity of precursor-synthesizing enzymes can function as radioprotectors.

\section{Regeneration (hematopoietic and immunostimulant compounds)}

IR exposure leads to dose-dependent defects of the lymphoid and hematopoietic systems through a complex cascade known as hematopoietic syndrome, which can result in septicemia and death (Guo et al. 2015). Hence, modulating the regeneration of hematopoietic cells and stimulating the immune system (e.g., by increasing the number of spleen colony-forming units) are effective therapeutic strategies for overcoming IR-induced damage. As such, various endogenous compounds such as immunemodulators, growth factors, and cytokines have been found to be effective radioprotectors. For example, the endogenous agents IL-1, TNF- $\alpha$, granulocyte colony-stimulating factor (G-CSF), stem cell factor (SCF), erythropoietin (EPO), and granulocyte-macrophage colony-stimulating factor (GM)-CSF have been investigated as potential radioprotectors. These agents stimulate stem cell progenitors and promote hematopoietic bone marrow (BM) repopulation (Dumont et al. 2010; Schaue et al. 2012). Hence, agents that upregulate endogenous radioprotective factors can also act as radioprotectors.

\section{Molecular-based radioprotection}

Recent studies have focused on understanding the signaling and apoptotic pathways involved in IR damage and identifying the events that occur late in these pathways as potential targets for post-irradiation intervention. For instance, ATM/ATR, a sensing protein and p53 tumor suppressor, regulates the DNA damage pathway. ATM/ ATR plays a key role in triggering apoptotic cell death by upregulating pro-apoptotic proteins such as Apaf-1, Noxa, and Bax after IR. Recent studies demonstrated that pifithrin- $\mu$, a small-molecule inhibitor of p53, protected thymocytes from IR-induced apoptosis and reduced IRinduced death when injected into mice before IR exposure (Strom et al. 2006). Similarly, overexpression of $\mathrm{Bcl} 2$, an 
inhibitor of pro-apoptotic proteins, in transgenic mice has also been shown to effectively increase the survival of irradiated mice by protecting against IR-induced apoptosis in hematopoietic cells (Erlacher et al. 2005). In addition, some studies have suggested that STAT3 protects against IR damage, and STAT3 can be activated by various growth factors. For example, the STAT3 activator CBLB502 was recently demonstrated to protect mice from IR-induced damage, and another study showed that STAT3 activation protects hair cells from IR-induced cell death (Xu et al. 2016). Nuclear factor-erythroid 2-related factor 2 (Nrf2) is a key transcriptional regulator of antioxidant and anti-inflammatory enzymes. Genetic upregulation of Nrf2 in the skin of SKH-1 hairless mice has been shown to protect against IR damage (Knatko et al. 2015). Importantly, heat shock proteins (HSPs) are cytoprotective and can mediate cell and tissue repair after deleterious effects of IR (Lee et al. 2001). Overexpression of one or more HSP genes has been shown to be sufficient to protect against IR exposure, and small molecules that can enhance the expression or function of HSPs have also shown promise for treatment of chronic or acute symptoms after IR. The radioprotective effects of HSPs have been shown to be related to apoptotic pathway interference (Akerfelt et al. 2010; Kim et al. 2006). Peroxisome proliferator-activated receptor- $\gamma$ (PPAR- $\gamma$ ) is part of the nuclear hormone receptor family, and PPAR- $\gamma$ agonists inhibit collagen deposition and TGF$\beta 1$-induced collagen secretion in bleomycin-induced pulmonary fibrosis (Milam et al. 2008). Rosiglitazone, a PPAR- $\gamma$ synthetic activator, suppresses IR-induced survival signals and DNA damage responses and enhances IRinduced apoptosis signaling in human cells (Mangoni et al. 2017). Moreover, PPAR- $\gamma$ is suggested to be an important regulator of fibroblast/myofibroblast activation. Therefore, PPAR- $\gamma$ ligands have also been suggested as novel therapeutic agents for IR-induced fibrotic lung diseases.

\section{Naturally occurring radioprotectors}

Amifostine is currently the only chemical drug approved by the FDA for protecting against the toxicity of radiotherapy in cancer patients. The free radical scavenger amifostine is an organic thiol phosphate prodrug and a chemical radioprotector similar to thiols, aminothiols, thiadiazoles, and benzothiazoles. However, the efficacy of such chemical radioprotectors is limited by their high toxicity and associated side effects (Andreassen et al. 2003). Indeed, amifostine has several clinically relevant limitations, including (1) an administration time within a narrow window (15-30 min before IR exposure); (2) approval only for intravenous (IV) administration (Yu et al. 2003); and (3) high toxicity associated with undesirable side effects including nausea, vomiting, cephalalgia, and hypotension.

However, many natural compounds, such as hormones and vitamins, also confer some level of radioprotection. For example, $\beta$-glucagon and the polysaccharide ginsan have multiple immunomodulatory effects and radioprotective activity (Luo and Luo 2009). Moreover, 5-androstenediol, a hormone produced by the adrenal cortex, and vitamins $\mathrm{C}$ and $\mathrm{E}$ have also been shown to exhibit radioprotective properties (Gonzalez et al. 2018; Tabeie et al. 2017; Whitnall et al. 2001). Some natural compounds including vitamin $\mathrm{C}$, glutamine, arginine, ubiquinone, and hydroquinone have been investigated for their ability to protect the immune system against IR. However, further in vivo and in vitro studies are necessary to validate these compounds as effective natural radioprotectors (Painuli and Kumar 2016).

Therefore, focus has shifted to the evaluation of natural product-based radioprotectors, given that they are less toxic, highly efficient, and inexpensive. For example, polyphenols, flavonoids, and a range of secondary metabolites are found in different plant parts and have radioprotective properties (Citrin et al. 2010; Pal et al. 2013). This review evaluates the radioprotective effects of several plant-derived compounds based on studies from the last 15-17 years that assessed their radioprotective potential and mechanisms.

\section{Apigenin}

Apigenin (4',5,7-trihydoxyflavone) is one of the most common flavonoids and is widely distributed throughout the leaves and stems of many dietary vegetables and fruits, including bell peppers, broccoli, celery, Chinese cabbage, French peas, garlic, guava, leeks, onions, tomatoes, snake ground, and wolfberry leaves (Miean and Mohamed 2001). It is also found in plant-derived beverages such as tea and wine (Shukla and Gupta 2010). Apigenin significantly decreases the frequency of IR-induced micronuclei (Rithidech et al. 2005). Additionally, apigenin treatment before IR significantly reduced DNA damage and nuclear buds in irradiated human peripheral blood lymphocytes, suggesting that apigenin protects lymphocytes from IRinduced cytogenetic alteration (Begum et al. 2012).

\section{Bergenin}

Bergenin has been isolated from the root extract of Caesalpinia digyna. This compound activates various signaling pathways, such as the ERK1/2, MAP kinase, and SAPK/ JNK pathways, and also induces TNF- $\alpha$, nitric oxide (NO), and IL-12 production in infected murine macrophages. Bergenin is a hydrolysable tannin derivative and exhibits 
anti-hepatotoxic, anti-ulcerogenic, anti-HIV, anti-arrhythmic, anti-malarial, anti-inflammatory, neuroprotective, and immunomodulatory effects (Dwivedi et al. 2017). Bergenin effectively protects against DNA damage, and it has been suggested that its hydroxyl radical scavenging activity is critical for this DNA damage protection (Veerapur et al. 2009).

\section{Caffeine}

Caffeine, a methyl xanthine derivative, has also demonstrated protective activities against IR damage (Kim et al. 2003). A cohort study of patients receiving radiotherapy for cervical cancer found an inverse correlation between caffeine ingestion at the time of radiation therapy and incidence of severe IR toxicities (Stelzer et al. 1994). Animal studies have also evaluated the effects of caffeine on mouse survival following exposure to lethal doses of IR. Caffeine decreased IR-induced skin damage associated with radiation therapy (Hebbar et al. 2002) and conferred radioprotection against IR-induced damage in hamster ovary cells (Kesavan and Natarajan 1985), rat liver mitochondria (Kamat et al. 2000), and plasmid DNA (Kumar et al. 2001). It has also been shown to have radioprotective properties in the BM chromosomes of mice, regardless of whether it was given before or after whole body IR (Farooqi and Kesavan 1992). Caffeine has both antioxidant and anti-inflammatory properties (Hall et al. 2015), which may contribute to its protective effects against IR-induced damage. Specifically, caffeine scavenges hydroxyl radicals (Brezova et al. 2009) and competes with oxygen for IR-induced electrons. Moreover, caffeine restores the normal cell cycle following IR-induced arrest in the G2 phase of mouse embryos (Grinfeld and Jacquet 1987), and this effect was dependent on protein synthesis (Jung and Streffer 1992). Finally, caffeine was demonstrated to reduce the amount of UV radiation-induced protein in melanoma cells (Ravi et al. 2008)

\section{Chlorogenic acid and quinic acid}

Chlorogenic acid (5-O-caffeoylquinic acid) is the ester form of caffeic acid and quinic acid and is in the hydroxycinnamic acid group (Chandrasekara and Shahidi 2010; Santana-Galvez et al. 2017). Chlorogenic acid is an important plant polyphenol and is widely distributed in the leaves and fruit of coffee beans. It is hydrolyzed by internal microflora into various aromatic acid metabolites including caffeic acid and quinic acid (Gonthier et al. 2003). Quinic acid (1,3,4,5-tetrahydroxycyclohexane carboxylic acid) is a naturally occurring polyphenol distributed in cocoa beans, coffee, wine, and fruits and can be chemically synthesized from chlorogenic acid. Coffee beans are the main source of chlorogenic acid and quinic acid (Santana-Galvez et al. 2017). In one study, the alkaline comet assay demonstrated that quinic acid and chlorogenic acid protected against DNA damage induced by IR, suggesting significant radioprotective effects of these compounds (Cinkilic et al. 2013).

\section{Coniferyl aldehyde and coniferyl alcohol}

Coniferyl aldehyde (CA) is isolated from the bark of $E u$ commia ulmoides Oliver and has been shown to induce heat shock transcription factor 1 (HSF1) and protect against IR-induced damage. CA also increases the stability of HSF1 by phosphorylating it at residue Ser326, resulting in increased expression of HSP27 and HSP70. Moreover, EKR1/2 activation was demonstrated to mediate HSF1 phosphorylation at Ser326 by CA. Simultaneous exposure of normal cells to CA and IR or the chemotherapy medication paclitaxel demonstrated protective effects of CA that were dependent on HSF1 Ser326 phosphorylation. Furthermore, IR-mediated decrease in BM cellularity and IRmediated increase in terminal deoxynucleotidyl transferase dUTP nick end labeling (TUNEL)-positive BM cells were both significantly inhibited by CA in mice. Studies using an A549 orthotopic lung tumor model indicated that CA did not affect IR-mediated decrease in lung tumor nodules while normal lung tissue was protected from irradiation. Taken together, these studies suggest that CA could be used to induce HSF1 and protect normal cells against IRand/or chemotherapeutic agent-induced damage (Kim et al. 2015; Nam et al. 2013). Another study demonstrated that coniferyl alcohol $(\mathrm{COH})$, a hydroxyl derivative of $\mathrm{CA}$, also activated HSF1. Further investigation demonstrated that the vinyl moiety of $\mathrm{CA}$ and $\mathrm{COH}$ is the pharmacophore essential for inducing HSF1, which may be useful in future studies for developing small molecules for cytoprotection of normal cells against IR damage (Choi et al. 2017).

\section{Curcumin}

Curcumin is mainly extracted from the roots of Curcuma lona and has been demonstrated to exert radioprotective effects and to possess antitumor properties (Perrone et al. 2015). For example, curcumin reduced pulmonary fibrosis and increased the survival of mice exposed to IR. Curcumin acts as a free radical scavenger, inhibiting IR-induced ROS generation (Verma 2016). Another study demonstrated that IR-induced cell death was decreased by curcumin treatment in MCF7 breast cancer cells (Swati et al. 2009). Curcumin has also demonstrated the dual actions of radioprotecting non-cancerous normal cells while radiosensitizing tumor cells, which was found to be mediated by its radical scavenging properties and cell cycle 
checkpoints (Sebastia et al. 2014). Additionally, curcumin ameliorated IR-induced cognitive deficits, including learning and memory defects, by enhancing the Nrf2 antioxidant signaling pathways (Xie et al. 2014). Recent study has also demonstrated that curcumin-based therapeutic nanoparticles protect normal cells by scavenging free radicals (Xie et al. 2017). Finally, there is evidence that curcumin is a potent anti-inflammatory molecule (Menon and Sudheer 2007; Okunieff et al. 2006) and increases the balance of antioxidants to oxidants (Tawfik et al. 2013).

\section{Delphinidin}

Delphinidin is an anthocyanidin compound that possesses strong anti-inflammatory and antioxidant effects, among other various biological activities (Jeong et al. 2016). It is abundantly found in pigmented vegetables, such as carrots, tomatoes, and red onions, and fruits, including cranberries and concord grapes (Yun et al. 2009). Among the anthocyanins, delphinidin demonstrates the strongest antioxidant activity due to the many hydroxyl radicals in its structure (Watson and Schonlau 2015). Delphinidin also protects normal tissues from high linear energy transfer radiation such as that of protons (Kim et al. 2018). Taken together, these properties suggest that delphinidin is a promising radioprotector.

\section{Epigallocatechin-3-gallate}

Epigallocatechin-3-gallate (EGCG) is the main polyphenolic constituent of green tea and is widely recognized as a powerful free radical scavenger. Studies have shown EGCG to be effective in treating several disorders (Zhu et al. 2016). Specifically, EGCG has demonstrated antiaging, anti-angiogenic, anti-arthritic, antiviral, anti-inflammatory, and neuroprotective effects. It has also been reported that EGCG increases the levels of several antioxidant enzymes, including glutamate cysteine ligase, superoxide dismutase (SOD), and heme oxygenase-1 (HO1) (Zhu et al. 2014), both in vitro and in vivo. Moreover, EGCG can decrease the radiosensitivity of cell systems and enhance DNA repair activity following sublethal IR damage (Pianetti et al. 2002). Furthermore, pretreatment with EGCG was shown to significantly enhance cell viability, maintain cell mitochondrial mass, and decrease the levels of apoptosis and ROS induced by IR in keratinocytes. The protective effects of EGCG in response to UV radiation, which consequently inhibit cutaneous photoaging, have been widely reported. In addition, one mouse study reported that EGCG demonstrated radioprotective effects against IR-induced damage as measured by the spleen index, hematological parameters, malondialdehyde level, and SOD activity (Guvvala et al. 2017; Zhang et al. 2016).

\section{Ferulic acid}

Ferulic acid is a monophenolic phenylpropanoid that occurs naturally in plants such as coffee beans, green tea leaves, and rice. Ferulic acid possesses anti-inflammatory and antioxidant activity that indicate potential protective effects against IR-induced toxicity (Das et al. 2014). Indeed, in vitro studies have demonstrated that the antioxidant properties of ferulic acid protect against IRinduced toxicity. Specifically, ferulic acid shows antioxidant activity against peroxyl radical-induced oxidation in neuronal culture and synaptosomal membranes (Kanski et al. 2002). Ferulic acid also scavenges ROS, such as hydroxyl radicals $\left({ }^{\circ} \mathrm{OH}\right)$ and peroxyl radicals $\left(\mathrm{RO}_{2}^{\circ}\right)$, as well as the stable free radical 1,1-diphenyl-2-picrylhydrazyl (DPPH) (Kanski et al. 2002; Kikuzaki et al. 2002). Pretreatment of lymphocytes and hepatocytes with ferulic acid resulted in a significant decrease in DNA damage and lipid peroxidation after IR exposure (Srinivasan et al. 2006). Furthermore, ferulic acid pretreatment significantly enhanced antioxidant defenses by upregulating antioxidant enzymes and reducing GSH level. Similarly, administration of ferulic acid prior to IR was shown to significantly reduce DNA damage in mouse blood leukocytes and bone marrow cells. In one study, ferulic acid given prior to or immediately after IR was shown to significantly reduce the level of micronucleated reticulocytes in mouse blood and to enhance DNA repair in mouse peripheral blood leukocytes (Maurya and Devasagayam 2013). Finally, one shortterm feeding study found that ferulic acid-sulfoglucuronide was the main metabolite in plasma when ferulic acid or its sugar esters were administered to rats (Zhao et al. 2003).

\section{Genistein}

Genistein (4',5,7-trihydroxyisoflavone), a soy isoflavone, has demonstrated protection against IR toxicities. The protective effects of genistein are mediated by a combination of activities within the cell, including free radicalscavenging activity, antioxidant activity, and anti-inflammatory activity (Davis et al. 2007). Genistein demonstrated protection against IR-induced damage to mouse BM by preserving neutrophils and platelets (Zhou and Mi 2005) and also protected BM progenitor cell populations to prevent hematopoietic stem cell pool exhaustion (Davis et al. 2008). Moreover, genistein has been shown to reduce IR damage in the lung and increase survival in mice receiving thoracic radiation (Day et al. 2008). Genistein also decreased the number of micronuclei in BM and lung fibroblasts, suggesting a reduction in IR-induced DNA 
damage (Mahmood et al. 2011; Para et al. 2009). In addition to the protective activities mentioned above, several other mechanisms have been proposed to mediate the radioprotective effects of genistein, including activation of the DNA repair enzyme Gadd45 (Grace et al. 2007), quiescence of the cell cycle at the G0/G1 phase (Tamulevicius et al. 2007), and inflammation suppression (Comalada et al. 2006; Ha et al. 2013). In addition, clinical data indicate that genistein can reduce intestinal, urinary, and sexual adverse effects when used in combination with radiation therapy to treat prostate cancer (Ahmad et al. 2010).

\section{Hesperidin}

Hesperidin (hesperetin-7-rhamnoglucoside) is a flavanone glycoside belonging to the flavonoid family. Hesperidin is the major flavonoid in lemons and sweet oranges and has radioprotective effects mediated by its anti-inflammatory and antioxidant properties. Specifically, it can prevent oxidative stress damage caused by IR exposure to lung tissue. Additionally, hesperidin was shown to protect against genetic damage to lymphocytes induced by the radiotracer 99mTc-MIBI in vitro (Fardid et al. 2016). In addition, hesperidin inhibited IR responses in rats (Rezaeyan et al. 2016) and demonstrated antioxidant and antiapoptotic activities in mouse testes injured by IR (Shaban et al. 2017).

\section{Lycopene}

Lycopene is a widely distributed dietary carotenoid found in red fruits and vegetables, such as tomatoes, pink guava, pink grape fruit, apricots, watermelon, and papaya (Gupta et al. 2015), and has demonstrated potential protective effects against IR damage. The antioxidant activities of lycopene have been extensively evaluated in vitro and in vivo and are mediated by its ability to scavenge ROS (Srinivasan et al. 2009). Previous studies also suggest that lycopene could reduce IR damage by removing singlet oxygen and scavenging free radicals (Kelkel et al. 2011). Lycopene pretreatment significantly decreased the frequency of micronuclei, dicentric aberration, and translocation in irradiated human lymphocytes and rat hepatocytes. IR-induced lipid peroxidation was also decreased by lycopene pretreatment, and the activity of antioxidant enzymes including SOD, catalase, and glutathione peroxidase was increased (Gajowik and Dobrzynska 2017; Srinivasan et al. 2009; Srinivasan et al. 2007).

\section{N-Acetyl tryptophan glucopyranoside (NATG)}

$\mathrm{N}$-acetyl tryptophan glucoside (NATG), a bacterial secondary metabolite, was purified from the radioresistant bacterium Bacillus subtilis. NATG pretreatment mediates radioprotection by preventing IR-induced apoptosis through increase of the cytoprotective cytokines IFN- $\gamma$, IL17A, and IL-12 (Malhotra et al. 2015). NATG pretreatment has also been demonstrated to protect J774A.1 macrophages against IR-induced DNA damage (Malhotra et al. 2016) and was able to significantly enhance antioxidant enzymes in response to IR-induced damage in murine macrophages (Malhotra et al. 2018).

\section{Sesamol}

Sesamol (3,4-methylenedioxyphenol), a component of sesame seeds and sesame oil, is a natural phenolic antioxidant (Joshi et al. 2005). Sesamol possesses strong ROS scavenging and antioxidant properties (Kanimozhi and Prasad 2009) and is able to protect against IR-induced DNA damage in human lymphocyte cells (Prasad et al. 2005). Additionally, sesamol significantly attenuates IRinduced DNA damage in the hematopoietic system of mice (Kumar et al. 2018), and reduces genotoxicity in bone marrow cells (Kumar et al. 2015). Further, it protects the gastrointestinal and hematopoietic systems against IR-induced injury in mice (Khan et al. 2015). The radioprotective effects of sesamol are mediated by ROS scavenging (Mishra et al. 2011) and enhancement of DNA repair activity (Nair and Nair 2010).

\section{Psoralidin}

Psoralidin is a natural phenolic compound that can be isolated from Psoralea corylifolia, which is widely used in traditional medicine. Structurally, psoralidin contains two hydroxyl groups, one conjugated lactone, one isopentenyl group, and an intramolecular ether linkage. Psoralidin exhibits a variety of biological activities including antiinflammatory (Yang et al. 2011), antioxidant (Pahari and Rohr 2009), and antitumor (Bronikowska et al. 2012) activities. Psoralidin also regulates the NF- $\mathrm{KB}$ pathway and PI3K-mediated Akt signaling pathway (Kumar et al. 2009). Additionally, psoralidin inhibits Syk-mediated activation of the PI3K-IKK-IкB signaling pathway (Chiou et al. 2011). Psoralidin has demonstrated potential as a radioprotector due to its anti-inflammatory effects in human lung fibroblasts and mice. Specifically, psoralidin decreased IR-induced cyclooxygenase (COX2) expression through regulation of the NF- $\kappa \mathrm{B}$ and PI3K/Akt pathways. Psoralidin also decreased IR-induced pro-inflammatory 
cytokines such as TNF- $\alpha$, TGF- $\beta$, IL-6, IL- $1 \alpha / \beta$, and ICAM-1 (Yang et al. 2011).

\section{Troxerutin}

Troxerutin is one derivative of the flavonoid rutin, which is isolated from Sophora japonica (Japanese pogoda tree), and it has been used for the treatment of chronic venous insufficiency disease (Adam et al. 2005; Vanscheidt et al. 2002). Troxerutin has been shown to improve capillary function and to reduce capillary fragility and abnormal leakage. Moreover, troxerutin has demonstrated antithrombotic, anti-erythrocytic, and fibrinolytic activity (Maurya et al. 2005). Studies indicate that troxerutin is safe and effective in elderly patients (Marhic 1991) and pregnant women (Wijayanegara et al. 1992). Troxerutin scavenges oxygen-derived free radicals (Kessler et al. 2002; Wenisch and Biffignandi 2001). During head and neck cancer radiotherapy, administration of a mixture of coumarin and troxerutin conferred protection to the oral mucosa and salivary glands (Grotz et al. 2001). Moreover, troxerutin has been shown to inhibit lipid peroxidation in the membranes of subcellular organelles and in normal tissue of tumor-bearing mice exposed to IR. Furthermore, administration of troxerutin resulted in protection of DNA in whole body-irradiated tumor-bearing mice. Importantly, troxerutin protected DNA in blood leukocytes and bone marrow cells, but it did not protect DNA in tumor cells. Troxerutin also enhanced DNA repair and conferred dosedependent radioprotection to mouse blood and BM cells (Maurya et al. 2004), and it inhibited micronuclei in mouse blood reticulocytes and human peripheral blood lymphocytes. Suggested molecular mechanisms of radioprotection by troxerutin include activation of AKT and inhibition of JNK, which result in reduced IR-induced PTEN activation (Xu et al. 2017).

\section{Vanillin}

Vanillin (4-hydroxy-3-methoxybenzaldehyde), the major component of natural vanilla, is one of the most widely used flavoring materials worldwide. The source of vanilla is the pod, or bean, of the tropical Vanilla orchid (Vanilla planifolia Andrews, V. fragrans Salisb. Ames). Vanillin has demonstrated antioxidant activities including inhibition of lipid peroxidation and scavenging of hydroxyl radicals (Harish et al. 2005). Vanillin and its analogs have also demonstrated anti-mutagenic or anti-genotoxic effects in cells and animals (King et al. 2007; Shaughnessy et al. 2001). Interestingly, oral administration of vanillin to mice after injection of mitomycin $\mathrm{C}$ decreased the frequency of micronucleated polychromatic erythrocytes by $50 \%$ (Inouye et al. 1988). Data suggest that the anti-mutagenic effects of vanillin may result from a mutation-dependent, error-free pathway for post-replication DNA repair (Ohta et al. 1988). This pathway inhibited chromosomal aberrations induced by IR in mice (Sasaki et al. 1990) and in V79 cells (Keshava et al. 1998), inhibited lipid peroxidation in rat liver mitochondria, and reduced DNA damage in the plasmid pBR322 (Kumar et al. 2000). Additionally, the vanillin derivative VND3207 (4-hydroxy-3,5-dimethoxybenzaldehyde) reduced IR damage through antioxidant activities. Specifically, VND3207 treatment before IR significantly reduced DNA damage and activated the Akt pathway to induce survival (Zheng et al. 2008).

\section{Zingerone}

Zingerone is present at a level of about 9\% in ginger (Zingiber officinale), which is the most commonly used spice worldwide. Zingerone demonstrates potent pharmacological activities including antioxidant, anti-inflammatory, anticancer, and antimicrobial activities (Ahmad et al. 2015). Zingerone treatment to human lymphocytes prior to IR reduced micronuclei, apoptosis, and ROS generation, and alkaline comet tail determination also showed decreased comet tail moments (Rao et al. 2011). Further, zingerone also protected against IR-induced oxidative stress and DNA damage in Chinese hamster fibroblast cells (Rao and Rao 2010), demonstrating its potential as a possible radioprotector.

\section{Zymosan A}

Zymosan A is a glucan derived from the cell wall of Saccharomyces cerevisiae. Zymosan contains repeating glucose units connected by $\beta-1,3$-glycosidic linkages. In macrophages, zymosan A induced pro-inflammatory cytokines, arachidonate mobilization, inositol phosphate formation, and protein phosphorylation (Sato et al. 2003). Zymosan A exhibits radioprotective effects through regulating the immune system and inflammatory response. Specifically, zymosan A activates Toll-like receptor 2 on macrophages to induce inflammatory signaling. Toll-like receptor 2 has a critical role in recognizing specific components of pathogenic microorganisms (Underhill 2003) and cooperates with Toll-like receptor 6 and CD14 in response to zymosan A. Zymosan A is also recognized by Dectin-1, and the recognition of zymosan A triggers macrophages and dendritic cells to induce inflammatory signals (Gantner et al. 2003; Ozinsky et al. 2000). Zymosan A protected mouse cells from radiation-induced apoptosis by upregulating cytokines such as G-CSF, GM-CSF, IL-6, and IL-12. Zymosan A also protected cells from IR-induced DNA damage and reduced the number of $\gamma-\mathrm{H} 2 \mathrm{AX}$ foci that were caused by IR (Du et al. 2018). 


\section{Conclusion}

An ideal radioprotector should be easily available, affordably priced, and not result in serious toxicities over a wide dose range. It should also demonstrate an absence of cumulative effects from repeated treatments, be able to be orally administered, have a protective effect on widespread organ systems, and demonstrate efficacy for different types of radiation (X, gamma, electron, and neutron). Finally, it should possess a reasonable dose reduction factor and an ability to act through multiple mechanisms (Cheki et al. 2016). A large number of pharmacological agents are currently being developed to prevent, mitigate, or treat IRinduced toxicities. Even though the use of radioprotectors is a very promising approach for both accidental and therapeutic exposure, no available radioprotectors are capable of completely preventing IR-related toxicities. Therefore, the use of naturally occurring compounds may be a good strategy in the development of ideal radioprotectors.

The work summarized here proposes that multiple potential radioprotectors exist with different targets and mechanisms. Radioprotectors mitigate IR-induced injury and/or IR-related syndromes by preventing or destroying free radicals, activating enzymes involved in the repair of DNA breaks, stimulating hematopoiesis and the immune system, or interacting with proteins in signaling and apoptotic execution pathways (Fig. 5; Table 2). These radioprotective agents include both synthetic chemical compounds and natural products. However, naturally occurring compounds have notable benefits for use in radioprotection. The major advantage of using naturally occurring compounds is their increased safety relative to synthetic chemical compounds. Moreover, natural products have been shown to be effective in curing symptoms similar to those of radiation syndrome. Studies exploring these compounds as a novel approach to radioprotection have demonstrated the effectiveness of plant-derived compounds in treating various human ailments all over the world.

Considering the pressing need for efficient and safe medicinal resources and the broad range of circumstances in which radioprotectors are required, future efforts to develop natural radioprotectors remain extremely important.

Acknowledgements This work was supported by Grants from the National Research Foundation of Korea, (2017R1A2B2002327, 2017M2A2A702019560, and 2018R1A5A2025286), funded by the Korean government (Ministry of Science and ICT).

\section{Compliance with ethical standards}

Conflict of interest All authors declared no conflict of interest.
Open Access This article is distributed under the terms of the Creative Commons Attribution 4.0 International License (http://crea tivecommons.org/licenses/by/4.0/), which permits unrestricted use, distribution, and reproduction in any medium, provided you give appropriate credit to the original author(s) and the source, provide a link to the Creative Commons license, and indicate if changes were made.

\section{References}

Adam BS, Pentz R, Siegers CP, Strubelt O, Tegtmeier M (2005) Troxerutin protects the isolated perfused rat liver from a possible lipid peroxidation by coumarin. Phytomedicine 12:52-61

Ahmad IU, Forman JD, Sarkar FH, Hillman GG, Heath E, Vaishampayan U, Cher ML, Andic F, Rossi PJ, Kucuk O (2010) Soy isoflavones in conjunction with radiation therapy in patients with prostate cancer. Nutr Cancer 62:996-1000

Ahmad B, Rehman MU, Amin I, Arif A, Rasool S, Bhat SA, Afzal I, Hussain I, Bilal S, Mir M (2015) A review on pharmacological properties of zingerone (4-(4-Hydroxy-3-methoxyphenyl)-2-butanone). Sci World J 2015:816364

Akerfelt M, Morimoto RI, Sistonen L (2010) Heat shock factors: integrators of cell stress, development and lifespan. Nat Rev Mol Cell Biol 11:545-555

Andreassen CN, Grau C, Lindegaard JC (2003) Chemical radioprotection: a critical review of amifostine as a cytoprotector in radiotherapy. Semin Radiat Oncol 13:62-72

Basile LA, Ellefson D, Gluzman-Poltorak Z, Junes-Gill K, Mar V, Mendonca S, Miller JD, Tom J, Trinh A, Gallaher TK (2012) HemaMax, a recombinant human interleukin-12, is a potent mitigator of acute radiation injury in mice and non-human primates. PLoS ONE 7:e30434

Begum N, Prasad NR, Kanimozhi G, Hasan AQ (2012) Apigenin ameliorates gamma radiation-induced cytogenetic alterations in cultured human blood lymphocytes. Mutat Res 747:71-76

Bourgier C, Levy A, Vozenin MC, Deutsch E (2012) Pharmacological strategies to spare normal tissues from radiation damage: useless or overlooked therapeutics? Cancer Metastasis Rev 31:699-712

Brezova V, Slebodova A, Stasko A (2009) Coffee as a source of antioxidants: an EPR study. Food Chem 114:859-868

Bronikowska J, Szliszka E, Jaworska D, Czuba ZP, Krol W (2012) The coumarin psoralidin enhances anticancer effect of tumor necrosis factor-related apoptosis-inducing ligand (TRAIL). Molecules 17:6449-6464

Burdelya LG, Krivokrysenko VI, Tallant TC, Strom E, Gleiberman AS, Gupta D, Kurnasov OV, Fort FL, Osterman AL, Didonato JA, Feinstein E, Gudkov AV (2008) An agonist of toll-like receptor 5 has radioprotective activity in mouse and primate models. Science 320:226-230

Chandrasekara A, Shahidi F (2010) Content of insoluble bound phenolics in millets and their contribution to antioxidant capacity. J Agric Food Chem 58:6706-6714

Cheki M, Mihandoost E, Shirazi A, Mahmoudzadeh A (2016) Prophylactic role of some plants and phytochemicals against radio-genotoxicity in human lymphocytes. J Cancer Res Ther 12:1234-1242

Chiou WF, Don MJ, Liao JF, Wei BL (2011) Psoralidin inhibits LPSinduced iNOS expression via repressing Syk-mediated activation of PI3 K-IKK-IkappaB signaling pathways. Eur J Pharmacol 650:102-109

Choi SK, Mun GI, Choi E, Kim SY, Kwon Y, Na Y, Lee YS (2017) The conjugated double bond of coniferyl aldehyde is essential 
for heat shock factor 1 mediated cytotoprotection. J Nat Prod 80:2379-2383

Cinkilic N, Cetintas SK, Zorlu T, Vatan O, Yilmaz D, Cavas T, Tunc S, Ozkan L, Bilaloglu R (2013) Radioprotection by two phenolic compounds: chlorogenic and quinic acid, on X-ray induced DNA damage in human blood lymphocytes in vitro. Food Chem Toxicol 53:359-363

Citrin D, Cotrim AP, Hyodo F, Baum BJ, Krishna MC, Mitchell JB (2010) Radioprotectors and mitigators of radiation-induced normal tissue injury. Oncologist 15:360-371

Comalada M, Ballester I, Bailon E, Sierra S, Xaus J, Galvez J, De Medina FS, Zarzuelo A (2006) Inhibition of pro-inflammatory markers in primary bone marrow-derived mouse macrophages by naturally occurring flavonoids: analysis of the structureactivity relationship. Biochem Pharmacol 72:1010-1021

Culy CR, Spencer CM (2001) Amifostine: an update on its clinical status as a cytoprotectant in patients with cancer receiving chemotherapy or radiotherapy and its potential therapeutic application in myelodysplastic syndrome. Drugs 61:641-684

Das U, Manna K, Sinha M, Datta S, Das DK, Chakraborty A, Ghosh M, Saha KD, Dey S (2014) Role of ferulic acid in the amelioration of ionizing radiation induced inflammation: a murine model. PLoS ONE 9:e97599

Davis TA, Clarke TK, Mog SR, Landauer MR (2007) Subcutaneous administration of genistein prior to lethal irradiation supports multilineage, hematopoietic progenitor cell recovery and survival. Int J Radiat Biol 83:141-151

Davis TA, Mungunsukh O, Zins S, Day RM, Landauer MR (2008) Genistein induces radioprotection by hematopoietic stem cell quiescence. Int J Radiat Biol 84:713-726

Day RM, Barshishat-Kupper M, Mog SR, Mccart EA, Prasanna PG, Davis TA, Landauer MR (2008) Genistein protects against biomarkers of delayed lung sequelae in mice surviving high-dose total body irradiation. J Radiat Res 49:361-372

Di Maggio FM, Minafra L, Forte GI, Cammarata FP, Lio D, Messa C, Gilardi MC, Bravata V (2015) Portrait of inflammatory response to ionizing radiation treatment. J Inflamm (Lond) 12:14

Du J, Zhang P, Zhao H, Dong S, Yang Y, Cui J, Gao F, Cai J, Liu C (2018) The mechanism for the radioprotective effects of zymosan-A in mice. J Cell Mol Med 22:2413-2421

Dumont F, Le Roux A, Bischoff P (2010) Radiation countermeasure agents: an update. Expert Opin Ther Pat 20:73-101

Dwivedi VP, Bhattacharya D, Yadav V, Singh DK, Kumar S, Singh M, Ojha D, Ranganathan A, Van Kaer L, Chattopadhyay D, Das G (2017) The phytochemical bergenin enhances T Helper 1 responses and anti-mycobacterial immunity by activating the MAP kinase pathway in macrophages. Front Cell Infect Microbiol 7:149

Erlacher M, Michalak EM, Kelly PN, Labi V, Niederegger H, Coultas L, Adams JM, Strasser A, Villunger A (2005) BH3-only proteins Puma and Bim are rate-limiting for gamma-radiation- and glucocorticoid-induced apoptosis of lymphoid cells in vivo. Blood 106:4131-4138

Fardid R, Ghorbani Z, Haddadi G, Behzad-Behbahani A, Arabsolghar R, Kazemi E, Okhovat MA, Hosseinimehr SJ (2016) Effects of hesperidin as a radio-protector on apoptosis in rat peripheral blood lymphocytes after gamma radiation. J Biomed Phys Eng 6:217-228

Farese AM, Cohen MV, Katz BP, Smith CP, Gibbs A, Cohen DM, Macvittie TJ (2013) Filgrastim improves survival in lethally irradiated nonhuman primates. Radiat Res 179:89-100

Farooqi Z, Kesavan PC (1992) Radioprotection by caffeine pre- and post-treatment in the bone marrow chromosomes of mice given whole-body gamma-irradiation. Mutat Res 269:225-230
Finch PW, Rubin JS (2004) Keratinocyte growth factor/fibroblast growth factor 7, a homeostatic factor with therapeutic potential for epithelial protection and repair. Adv Cancer Res 91:69-136

Gajowik A, Dobrzynska MM (2017) The evaluation of protective effect of lycopene against genotoxic influence of X-irradiation in human blood lymphocytes. Radiat Environ Biophys 56:413-422

Gantner BN, Simmons RM, Canavera SJ, Akira S, Underhill DM (2003) Collaborative induction of inflammatory responses by dectin-1 and Toll-like receptor 2. J Exp Med 197:1107-1117

Garofalo MC, Ward AA, Farese AM, Bennett A, Taylor-Howell C, Cui W, Gibbs A, Prado KL, Macvittie TJ (2014) A pilot study in rhesus macaques to assess the treatment efficacy of a small molecular weight catalytic metalloporphyrin antioxidant (AEOL 10150) in mitigating radiation-induced lung damage. Health Phys 106:73-83

Gluzman-Poltorak Z, Mendonca SR, Vainstein V, Kha H, Basile LA (2014) Randomized comparison of single dose of recombinant human IL-12 versus placebo for restoration of hematopoiesis and improved survival in rhesus monkeys exposed to lethal radiation. J Hematol Oncol 7:31

Gonthier MP, Verny MA, Besson C, Remesy C, Scalbert A (2003) Chlorogenic acid bioavailability largely depends on its metabolism by the gut microflora in rats. J Nutr 133:1853-1859

Gonzalez E, Cruces MP, Pimentel E, Sanchez P (2018) Evidence that the radioprotector effect of ascorbic acid depends on the radiation dose rate. Environ Toxicol Pharmacol 62:210-214

Gourmelon P, Benderitter M, Bertho JM, Huet C, Gorin NC, De Revel P (2010) European consensus on the medical management of acute radiation syndrome and analysis of the radiation accidents in Belgium and Senegal. Health Phys 98:825-832

Grace M, Blakely W, Landauer M (2007) Genistein-induced alterations of radiation-responsive gene expression. Radiat Meas 42:1152-1157

Grinfeld S, Jacquet P (1987) An unusual radiation-induced G2 arrest in the zygote of the BALB/c mouse strain. Int J Radiat Biol Relat Stud Phys Chem Med 51:353-363

Grotz KA, Wustenberg P, Kohnen R, Al-Nawas B, Henneicke-Von Zepelin HH, Bockisch A, Kutzner J, Naser-Hijazi B, Belz GG, Wagner W (2001) Prophylaxis of radiogenic sialadenitis and mucositis by coumarin/troxerutine in patients with head and neck cancer-a prospective, randomized, placebo-controlled, double-blind study. Br J Oral Maxillofac Surg 39:34-39

Guo CY, Luo L, Urata Y, Goto S, Huang WJ, Takamura S, Hayashi F, Doi H, Kitajima Y, Ono Y, Ogi T, Li TS (2015) Sensitivity and dose dependency of radiation-induced injury in hematopoietic stem/progenitor cells in mice. Sci Rep 5:8055

Gupta S, Jawanda MK, Arora V, Mehta N, Yadav V (2015) Role of lycopene in preventing oral diseases as a nonsurgical aid of treatment. Int J Prev Med 6:70

Guvvala PR, Ravindra JP, Rajani CV, Sivaram M, Selvaraju S (2017) Protective role of epigallocatechin-3-gallate on arsenic induced testicular toxicity in Swiss albino mice. Biomed Pharmacother 96:685-694

Ha CT, Li XH, Fu D, Xiao M, Landauer MR (2013) Genistein nanoparticles protect mouse hematopoietic system and prevent proinflammatory factors after gamma irradiation. Radiat Res 180:316-325

Hall EJ, Giaccia AJ (2012) Radiobiology for the radiologist, 7th edn. Lippincott Williams \& Wilkins, Wolters Kluwer Health, Philadelphia, p 576

Hall S, Desbrow B, Anoopkumar-Dukie S, Davey AK, Arora D, Mcdermott C, Schubert MM, Perkins AV, Kiefel MJ, Grant GD (2015) A review of the bioactivity of coffee, caffeine and key coffee constituents on inflammatory responses linked to depression. Food Res Int 76:626-636 
Hammond WT, Bradley EL, Welsh RE, Qian J, Weisenberger AG, Smith MF, Majewski S, Saha MS (2007) A gamma camera reevaluation of potassium iodide blocking efficiency in mice. Health Phys 92:396-406

Harish R, Divakar S, Srivastava A, Shivanandappa T (2005) Isolation of antioxidant compounds from the methanolic extract of the roots of Decalepis hamiltonii (Wight and Arn.). J Agric Food Chem 53:7709-7714

Hebbar SA, Mitra AK, George KC, Verma NC (2002) Caffeine ameliorates radiation-induced skin reactions in mice but does not influence tumour radiation response. J Radiol Prot 22:63-69

Hussar DA (2005) New drugs 05, part I. Nursing 35:54-61

Inouye T, Sasaki YF, Imanishi H, Watanabe M, Ohta T, Shirasu Y (1988) Suppression of mitomycin C-induced micronuclei in mouse bone marrow cells by post-treatment with vanillin. Mutat Res 202:93-95

Jeong MH, Ko H, Jeon H, Sung GJ, Park SY, Jun WJ, Lee YH, Lee J, Lee SW, Yoon HG, Choi KC (2016) Delphinidin induces apoptosis via cleaved HDAC3-mediated p53 acetylation and oligomerization in prostate cancer cells. Oncotarget 7:56767-56780

Joshi R, Kumar MS, Satyamoorthy K, Unnikrisnan MK, Mukherjee T (2005) Free radical reactions and antioxidant activities of sesamol: pulse radiolytic and biochemical studies. J Agric Food Chem 53:2696-2703

Jung T, Streffer C (1992) Effects of caffeine on protein phosphorylation and cell cycle progression in X-irradiated two-cell mouse embryos. Int J Radiat Biol 62:161-168

Kamat JP, Boloor KK, Devasagayam TP, Jayashree B, Kesavan PC (2000) Differential modification by caffeine of oxygen-dependent and independent effects of gamma-irradiation on rat liver mitochondria. Int J Radiat Biol 76:1281-1288

Kanimozhi P, Prasad NR (2009) Antioxidant potential of sesamol and its role on radiation-induced DNA damage in whole-body irradiated Swiss albino mice. Environ Toxicol Pharmacol 28:192-197

Kanski J, Aksenova M, Stoyanova A, Butterfield DA (2002) Ferulic acid antioxidant protection against hydroxyl and peroxyl radical oxidation in synaptosomal and neuronal cell culture systems in vitro: structure-activity studies. J Nutr Biochem 13:273-281

Kelkel M, Schumacher M, Dicato M, Diederich M (2011) Antioxidant and anti-proliferative properties of lycopene. Free Radic Res 45:925-940

Kesavan PC, Natarajan AT (1985) Protection and potentiation of radiation clastogenesis by caffeine: nature of possible initial events. Mutat Res 143:61-68

Keshava C, Keshava N, Ong TM, Nath J (1998) Protective effect of vanillin on radiation-induced micronuclei and chromosomal aberrations in V79 cells. Mutat Res 397:149-159

Kessler M, Ubeaud G, Walter T, Sturm F, Jung L (2002) Free radical scavenging and skin penetration of troxerutin and vitamin derivatives. J Dermatolog Treat 13:133-141

Khan S, Kumar A, Adhikari JS, Rizvi MA, Chaudhury NK (2015) Protective effect of sesamol against ${ }^{60} \mathrm{Co}$ gamma-ray-induced hematopoietic and gastrointestinal injury in C57BL/6 male mice. Free Radic Res 49:1344-1361

Kikuzaki H, Hisamoto M, Hirose K, Akiyama K, Taniguchi H (2002) Antioxidant properties of ferulic acid and its related compounds. J Agric Food Chem 50:2161-2168

Kim JK, Kim JH, Yoon YD (2003) Evaluation of caffeine as a radioprotector in whole-body irradiated male mice. Vivo 17:197-200

Kim HP, Morse D, Choi AM (2006) Heat-shock proteins: new keys to the development of cytoprotective therapies. Expert Opin Ther Targets 10:759-769
Kim SY, Lee HJ, Nam JW, Seo EK, Lee YS (2015) Coniferyl aldehyde reduces radiation damage through increased protein stability of heat shock transcriptional factor 1 by phosphorylation. Int J Radiat Oncol Biol Phys 91:807-816

Kim HM, Kim SH, Kang BS (2018) Radioprotective effects of delphinidin on normal human lung cells against proton beam exposure. Nutr Res Pract 12:41-46

King AA, Shaughnessy DT, Mure K, Leszczynska J, Ward WO, Umbach DM, Xu Z, Ducharme D, Taylor JA, Demarini DM, Klein CB (2007) Antimutagenicity of cinnamaldehyde and vanillin in human cells: global gene expression and possible role of DNA damage and repair. Mutat Res 616:60-69

Knatko EV, Ibbotson SH, Zhang Y, Higgins M, Fahey JW, Talalay P, Dawe RS, Ferguson J, Huang JT, Clarke R, Zheng S, Saito A, Kalra S, Benedict AL, Honda T, Proby CM, Dinkova-Kostova AT (2015) Nrf2 activation protects against solar-simulated ultraviolet radiation in mice and humans. Cancer Prev Res (Phila) 8:475-486

Krivokrysenko VI, Shakhov AN, Singh VK, Bone F, Kononov Y, Shyshynova I, Cheney A, Maitra RK, Purmal A, Whitnall MH, Gudkov AV, Feinstein E (2012) Identification of granulocyte colony-stimulating factor and interleukin-6 as candidate biomarkers of CBLB502 efficacy as a medical radiation countermeasure. J Pharmacol Exp Ther 343:497-508

Kumar SS, Ghosh A, Devasagayam TP, Chauhan PS (2000) Effect of vanillin on methylene blue plus light-induced single-strand breaks in plasmid pBR322 DNA. Mutat Res 469:207-214

Kumar SS, Devasagayam TP, Jayashree B, Kesavan PC (2001) Mechanism of protection against radiation-induced DNA damage in plasmid pBR322 by caffeine. Int $\mathrm{J}$ Radiat Biol 77:617-623

Kumar R, Srinivasan S, Koduru S, Pahari P, Rohr J, Kyprianou N, Damodaran C (2009) Psoralidin, an herbal molecule, inhibits phosphatidylinositol 3-kinase-mediated Akt signaling in androgen-independent prostate cancer cells. Cancer Prev Res (Phila) 2:234-243

Kumar A, Selvan TG, Tripathi AM, Choudhary S, Khan S, Adhikari JS, Chaudhury NK (2015) Sesamol attenuates genotoxicity in bone marrow cells of whole-body gamma-irradiated mice. Mutagenesis 30:651-661

Kumar A, Choudhary S, Adhikari JS, Chaudhury NK (2018) Sesamol ameliorates radiation induced DNA damage in hematopoietic system of whole body gamma-irradiated mice. Environ Mol Mutagen 59:79-90

Lanciano R, Sherman DM, Michalski J, Preston AJ, Yocom K, Friedman C (2001) The efficacy and safety of once-daily Kytril (granisetron hydrochloride) tablets in the prophylaxis of nausea and emesis following fractionated upper abdominal radiotherapy. Cancer Invest 19:763-772

Landauer MR, Srinivasan V, Seed TM (2003) Genistein treatment protects mice from ionizing radiation injury. J Appl Toxicol 23:379-385

Lee SJ, Choi SA, Lee KH, Chung HY, Kim TH, Cho CK, Lee YS (2001) Role of inducible heat shock protein 70 in radiationinduced cell death. Cell Stress Chaperones 6:273-281

Lee JC, Krochak R, Blouin A, Kanterakis S, Chatterjee S, Arguiri E, Vachani A, Solomides CC, Cengel KA, Christofidou-Solomidou M (2009) Dietary flaxseed prevents radiation-induced oxidative lung damage, inflammation and fibrosis in a mouse model of thoracic radiation injury. Cancer Biol Ther 8:47-53

Lobo V, Patil A, Phatak A, Chandra N (2010) Free radicals, antioxidants and functional foods: impact on human health. Pharmacogn Rev 4:118-126

Luo JZ, Luo L (2009) Ginseng on hyperglycemia: effects and mechanisms. Evid Based Complement Alternat Med 6:423-427 
Mahmood J, Jelveh S, Calveley V, Zaidi A, Doctrow SR, Hill RP (2011) Mitigation of radiation-induced lung injury by genistein and EUK-207. Int J Radiat Biol 87:889-901

Malhotra P, Adhikari M, Singh SK, Kumar R (2015) N-acetyl tryptophan glucopyranoside (NATG) provides radioprotection to murine macrophage J774A.1 cells. Free Radic Res 49:1488-1498

Malhotra P, Adhikari M, Mishra S, Singh S, Kumar P, Singh SK, Kumar R (2016) N-acetyl tryptophan glucopyranoside (NATG) as a countermeasure against gamma radiation-induced immunosuppression in murine macrophage J774A.1 cells. Free Radic Res 50:1265-1278

Malhotra P, Gupta AK, Singh D, Mishra S, Singh SK, Kumar R (2018) N-Acetyl-tryptophan glucoside (NATG) protects J774A.1 murine macrophages against gamma radiation-induced cell death by modulating oxidative stress. Mol Cell Biochem 447:9-19

Mangoni M, Sottili M, Gerini C, Desideri I, Bastida C, Pallotta S, Castiglione F, Bonomo P, Meattini I, Greto D, Cappelli S, Di Brina L, Loi M, Biti G, Livi L (2017) A PPAR-gamma agonist protects from radiation-induced intestinal toxicity. United Eur Gastroenterol J 5:218-226

Marhic C (1991) Clinical and rheological efficacy of troxerutin in obstetric gynecology. Rev Fr Gynecol Obstet 86:209-212

Maurya DK, Devasagayam TP (2013) Ferulic acid inhibits gamma radiation-induced DNA strand breaks and enhances the survival of mice. Cancer Biother Radiopharm 28:51-57

Maurya DK, Salvi VP, Krishnan Nair CK (2004) Radioprotection of normal tissues in tumor-bearing mice by troxerutin. J Radiat Res 45:221-228

Maurya DK, Balakrishnan S, Salvi VP, Nair CK (2005) Protection of cellular DNA from gamma-radiation-induced damages and enhancement in DNA repair by troxerutin. Mol Cell Biochem 280:57-68

Menon VP, Sudheer AR (2007) Antioxidant and anti-inflammatory properties of curcumin. Adv Exp Med Biol 595:105-125

Miean KH, Mohamed S (2001) Flavonoid (myricetin, quercetin, kaempferol, luteolin, and apigenin) content of edible tropical plants. J Agric Food Chem 49:3106-3112

Milam JE, Keshamouni VG, Phan SH, Hu B, Gangireddy SR, Hogaboam CM, Standiford TJ, Thannickal VJ, Reddy RC (2008) PPAR-gamma agonists inhibit profibrotic phenotypes in human lung fibroblasts and bleomycin-induced pulmonary fibrosis. Am J Physiol Lung Cell Mol Physiol 294:L891-L901

Mishra K, Srivastava PS, Chaudhury NK (2011) Sesamol as a potential radioprotective agent: in vitro studies. Radiat Res 176:613-623

Moding EJ, Kastan MB, Kirsch DG (2013) Strategies for optimizing the response of cancer and normal tissues to radiation. Nat Rev Drug Discov 12:526-542

Nair GG, Nair CK (2010) Protection of cellular DNA and membrane from gamma-radiation-induced damages and enhancement in DNA repair by sesamol. Cancer Biother Radiopharm 25:629-635

Nam JW, Kim SY, Yoon T, Lee YJ, Kil YS, Lee YS, Seo EK (2013) Heat shock factor 1 inducers from the bark of Eucommia ulmoides as cytoprotective agents. Chem Biodivers 10:1322-1327

Ohta T, Watanabe M, Shirasu Y, Inoue T (1988) Post-replication repair and recombination in uvrA umuC strains of Escherichia coli are enhanced by vanillin, an antimutagenic compound. Mutat Res 201:107-112

Okunieff P, Xu J, Hu D, Liu W, Zhang L, Morrow G, Pentland A, Ryan JL, Ding I (2006) Curcumin protects against radiationinduced acute and chronic cutaneous toxicity in mice and decreases mRNA expression of inflammatory and fibrogenic cytokines. Int J Radiat Oncol Biol Phys 65:890-898
Ormsby RJ, Lawrence MD, Blyth BJ, Bexis K, Bezak E, Murley JS, Grdina DJ, Sykes PJ (2014) Protection from radiation-induced apoptosis by the radioprotector amifostine (WR-2721) is radiation dose dependent. Cell Biol Toxicol 30:55-66

Orrell RW (2006) AEOL-10150 (Aeolus). Curr Opin Investig Drugs 7:70-80

Ozinsky A, Underhill DM, Fontenot JD, Hajjar AM, Smith KD, Wilson CB, Schroeder L, Aderem A (2000) The repertoire for pattern recognition of pathogens by the innate immune system is defined by cooperation between toll-like receptors. Proc Natl Acad Sci USA 97:13766-13771

Pahari P, Rohr J (2009) Total synthesis of psoralidin, an anticancer natural product. J Org Chem 74:2750-2754

Painuli S, Kumar N (2016) Prospects in the development of natural radioprotective therapeutics with anti-cancer properties from the plants of Uttarakhand region of India. J Ayurveda Integr Med 7:62-68

Pal S, Saha C, Dey SK (2013) Studies on black tea (Camellia sinensis) extract as a potential antioxidant and a probable radioprotector. Radiat Environ Biophys 52:269-278

Para AE, Bezjak A, Yeung IW, Van Dyk J, Hill RP (2009) Effects of genistein following fractionated lung irradiation in mice. Radiother Oncol 92:500-510

Perrone D, Ardito F, Giannatempo G, Dioguardi M, Troiano G, Lo Russo L, Del A, Laino L, Lo Muzio L (2015) Biological and therapeutic activities, and anticancer properties of curcumin. Exp Ther Med 10:1615-1623

Pianetti S, Guo S, Kavanagh KT, Sonenshein GE (2002) Green tea polyphenol epigallocatechin-3 gallate inhibits Her-2/neu signaling, proliferation, and transformed phenotype of breast cancer cells. Cancer Res 62:652-655

Prasad NR, Menon VP, Vasudev V, Pugalendi KV (2005) Radioprotective effect of sesamol on gamma-radiation induced DNA damage, lipid peroxidation and antioxidants levels in cultured human lymphocytes. Toxicology 209:225-235

Rao BN, Rao BS (2010) Antagonistic effects of Zingerone, a phenolic alkanone against radiation-induced cytotoxicity, genotoxicity, apoptosis and oxidative stress in Chinese hamster lung fibroblast cells growing in vitro. Mutagenesis 25:577-587

Rao BN, Archana PR, Aithal BK, Rao BS (2011) Protective effect of zingerone, a dietary compound against radiation induced genetic damage and apoptosis in human lymphocytes. Eur J Pharmacol 657:59-66

Ravi D, Muniyappa H, Das KC (2008) Caffeine inhibits UV-mediated NF-kappaB activation in A2058 melanoma cells: an ATMPKCdelta-p38 MAPK-dependent mechanism. Mol Cell Biochem 308:193-200

Rezaeyan A, Fardid R, Haddadi GH, Takhshid MA, Hosseinzadeh M, Najafi M, Salajegheh A (2016) Evaluating radioprotective effect of hesperidin on acute radiation damage in the lung tissue of rats. J Biomed Phys Eng 6:165-174

Rithidech KN, Tungjai M, Whorton EB (2005) Protective effect of apigenin on radiation-induced chromosomal damage in human lymphocytes. Mutat Res 585:96-104

Santana-Galvez J, Cisneros-Zevallos L, Jacobo-Velazquez DA (2017) Chlorogenic acid: recent advances on its dual role as a food additive and a nutraceutical against metabolic syndrome. Molecules 22:358

Sasaki YF, Ohta T, Imanishi H, Watanabe M, Matsumoto K, Kato T, Shirasu Y (1990) Suppressing effects of vanillin, cinnamaldehyde, and anisaldehyde on chromosome aberrations induced by X-rays in mice. Mutat Res 243:299-302

Sato M, Sano H, Iwaki D, Kudo K, Konishi M, Takahashi H, Takahashi T, Imaizumi H, Asai Y, Kuroki Y (2003) Direct binding of toll-like receptor 2 to zymosan, and zymosan-induced NF-kappa B activation and TNF-alpha secretion are down- 
regulated by lung collectin surfactant protein A. J Immunol 171:417-425

Schaue D, Kachikwu EL, Mcbride WH (2012) Cytokines in radiobiological responses: a review. Radiat Res 178:505-523

Sebastia N, Montoro A, Hervas D, Pantelias G, Hatzi VI, Soriano JM, Villaescusa JI, Terzoudi GI (2014) Curcumin and trans-resveratrol exert cell cycle-dependent radioprotective or radiosensitizing effects as elucidated by the PCC and G2-assay. Mutat Res 766-767:49-55

Shaban NZ, Ahmed Zahran AM, El-Rashidy FH, Abdo Kodous AS (2017) Protective role of hesperidin against gamma-radiationinduced oxidative stress and apoptosis in rat testis. J Biol Res (Thessalon) 24:5

Sharygin VL, Pulatova MK, Shliakova TG, Mitrokhin IuI, Todorov IN (2005) Activation of deoxyribonucleotide synthesis by radioprotectants and antioxidants as a key stage in formation of body resistance to DNA-damaging factors. Izv Akad Nauk Ser Biol 4:401-422

Shaughnessy DT, Setzer RW, Demarini DM (2001) The antimutagenic effect of vanillin and cinnamaldehyde on spontaneous mutation in Salmonella TA104 is due to a reduction in mutations at GC but not AT sites. Mutat Res 480-481:55-69

Shukla S, Gupta S (2010) Apigenin: a promising molecule for cancer prevention. Pharm Res 27:962-978

Singh VK, Romaine PL, Seed TM (2015) Medical countermeasures for radiation exposure and related injuries: characterization of medicines, FDA-approval status and inclusion into the strategic national stockpile. Health Phys 108:607-630

Srinivasan M, Rajendra Prasad N, Menon VP (2006) Protective effect of curcumin on gamma-radiation induced DNA damage and lipid peroxidation in cultured human lymphocytes. Mutat Res 611:96-103

Srinivasan M, Sudheer AR, Pillai KR, Kumar PR, Sudhakaran PR, Menon VP (2007) Lycopene as a natural protector against gamma-radiation induced DNA damage, lipid peroxidation and antioxidant status in primary culture of isolated rat hepatocytes in vitro. Biochim Biophys Acta 1770:659-665

Srinivasan M, Devipriya N, Kalpana KB, Menon VP (2009) Lycopene: an antioxidant and radioprotector against gammaradiation-induced cellular damages in cultured human lymphocytes. Toxicology 262:43-49

Stelzer KJ, Koh WJ, Kurtz H, Greer BE, Griffin TW (1994) Caffeine consumption is associated with decreased severe late toxicity after radiation to the pelvis. Int $\mathbf{J}$ Radiat Oncol Biol Phys 30:411-417

Stickney DR, Dowding C, Authier S, Garsd A, Onizuka-Handa N, Reading C, Frincke JM (2007) 5-androstenediol improves survival in clinically unsupported rhesus monkeys with radiation-induced myelosuppression. Int Immunopharmacol 7:500-505

Straub JM, New J, Hamilton CD, Lominska C, Shnayder Y, Thomas SM (2015) Radiation-induced fibrosis: mechanisms and implications for therapy. J Cancer Res Clin Oncol 141:1985-1994

Strom E, Sathe S, Komarov PG, Chernova OB, Pavlovska I, Shyshynova I, Bosykh DA, Burdelya LG, Macklis RM, Skaliter R, Komarova EA, Gudkov AV (2006) Small-molecule inhibitor of p53 binding to mitochondria protects mice from gamma radiation. Nat Chem Biol 2:474-479

Swati G, Ahmed M, Mishra K (2009) Enhancement of gamma radiation-induced cytotoxicity of breast cancer cells by curcumin. Mol Cell Pharmacol 1:208-217

Tabeie F, Tabatabaei SM, Mahmoud-Pashazadeh A, Assadi M (2017) Radioprotective effect of beta D-glucan and vitamin $\mathrm{E}$ on gamma irradiated mouse. J Clin Diagn Res 11:TC08-TC11

Tamulevicius P, Wang M, Iliakis G (2007) Homology-directed repair is required for the development of radioresistance during $\mathrm{S}$ phase: interplay between double-strand break repair and checkpoint response. Radiat Res 167:1-11

Tawfik SS, Abouelella AM, Shahein YE (2013) Curcumin protection activities against gamma-rays-induced molecular and biochemical lesions. BMC Res Notes 6:375

Thelander L (2007) Ribonucleotide reductase and mitochondrial DNA synthesis. Nat Genet 39:703-704

Underhill DM (2003) Macrophage recognition of zymosan particles. J Endotoxin Res 9:176-180

Vanscheidt W, Rabe E, Naser-Hijazi B, Ramelet AA, Partsch H, Diehm C, Schultz-Ehrenburg U, Spengel F, Wirsching M, Gotz V, Schnitker J, Henneicke-Von Zepelin HH (2002) The efficacy and safety of a coumarin-/troxerutin-combination (SB-LOT) in patients with chronic venous insufficiency: a double blind placebo-controlled randomised study. Vasa 31:185-190

Veerapur VP, Prabhakar KR, Parihar VK, Kandadi MR, Ramakrishana S, Mishra B, Satish Rao BS, Srinivasan KK, Priyadarsini KI, Unnikrishnan MK (2009) Ficus racemosa stem bark extract: a potent antioxidant and a probable natural radioprotector. Evid Based Complement Alternat Med 6:317-324

Verma V (2016) Relationship and interactions of curcumin with radiation therapy. World J Clin Oncol 7:275-283

Wang H, Mu X, He H, Zhang XD (2018) Cancer radiosensitizers. Trends Pharmacol Sci 39:24-48

Watson RR, Schonlau F (2015) Nutraceutical and antioxidant effects of a delphinidin-rich maqui berry extract Delphinol(R): a review. Minerva Cardioangiol 63:1-12

Wenisch C, Biffignandi PM (2001) Effect of bioflavonoids (trihydroxyethylrutin and disodium flavodate) in vitro on neutrophil reactive oxygen production and phagocytic ability assessed by flow cytometry. Curr Med Res Opin 17:123-127

Whitnall MH, Inal CE, Jackson WE, Miner VL, Villa V, Seed TM (2001) In vivo radioprotection by 5 -androstenediol: stimulation of the innate immune system. Radiat Res 156:283-293

Whitnall MH, Villa V, Seed TM, Benjack J, Miner V, Lewbart ML, Dowding CA, Jackson WE (2005) Molecular specificity of 5 -androstenediol as a systemic radioprotectant in mice. Immunopharmacol Immunotoxicol 27:15-32

Wijayanegara H, Mose JC, Achmad L, Sobarna R, Permadi W (1992) A clinical trial of hydroxyethylrutosides in the treatment of haemorrhoids of pregnancy. J Int Med Res 20:54-60

Wirsdorfer F, Jendrossek V (2016) The role of lymphocytes in radiotherapy-induced adverse late effects in the lung. Front Immunol 7:591

Xie Y, Zhao QY, Li HY, Zhou X, Liu Y, Zhang H (2014) Curcumin ameliorates cognitive deficits heavy ion irradiation-induced learning and memory deficits through enhancing of $\mathrm{Nrf} 2$ antioxidant signaling pathways. Pharmacol Biochem Behav 126:181-186

Xie J, Yong Y, Dong X, Du J, Guo Z, Gong L, Zhu S, Tian G, Yu S, $\mathrm{Gu}$ Z, Zhao Y (2017) Therapeutic nanoparticles based on curcumin and bamboo charcoal nanoparticles for chemo-photothermal synergistic treatment of cancer and radioprotection of normal cells. ACS Appl Mater Interfaces 9:14281-14291

Xiong GL, Zhao Y, Xing S, Shen X, Ning XC, Lu SX, Li J, Guo LL, Hao R, Chen TC, Miao JL, He JC, Luo QL (2013) Radiation protection effect of rhIL-12 on monkey hematopoietic system. Zhongguo Shi Yan Xue Ye Xue Za Zhi 21:150-154

Xu Y, Dong H, Ge C, Gao Y, Liu H, Li W, Zhang C (2016) CBLB502 administration protects gut mucosal tissue in ulcerative colitis by inhibiting inflammation. Ann Transl Med 4:301

Xu P, Zhang WB, Cai XH, Qiu PY, Hao MH, Lu DD (2017) Activating AKT to inhibit JNK by troxerutin antagonizes radiation-induced PTEN activation. Eur J Pharmacol 795:66-74

Yang HJ, Youn H, Seong KM, Yun YJ, Kim W, Kim YH, Lee JY, Kim CS, Jin YW, Youn B (2011) Psoralidin, a dual inhibitor of 
COX-2 and 5-LOX, regulates ionizing radiation (IR)-induced pulmonary inflammation. Biochem Pharmacol 82:524-534

Yu Z, Eaton JW, Persson HL (2003) The radioprotective agent, amifostine, suppresses the reactivity of intralysosomal iron. Redox Rep 8:347-355

Yun JM, Afaq F, Khan N, Mukhtar H (2009) Delphinidin, an anthocyanidin in pigmented fruits and vegetables, induces apoptosis and cell cycle arrest in human colon cancer HCT116 cells. Mol Carcinog 48:260-270

Zhang S, Liu X, Mei L, Wang H, Fang F (2016) Epigallocatechin-3gallate (EGCG) inhibits imiquimod-induced psoriasis-like inflammation of BALB/c mice. BMC Complement Altern Med $16: 334$

Zhao Z, Egashira Y, Sanada H (2003) Ferulic acid sugar esters are recovered in rat plasma and urine mainly as the sulfoglucuronide of ferulic acid. J Nutr 133:1355-1361
Zheng H, Chen ZW, Wang L, Wang SY, Yan YQ, Wu K, Xu QZ, Zhang SM, Zhou PK (2008) Radioprotection of 4-hydroxy-3,5dimethoxybenzaldehyde (VND3207) in culture cells is associated with minimizing DNA damage and activating Akt. Eur $\mathbf{J}$ Pharm Sci 33:52-59

Zhou Y, Mi MT (2005) Genistein stimulates hematopoiesis and increases survival in irradiated mice. J Radiat Res 46:425-433

Zhu W, Xu J, Ge Y, Cao H, Ge X, Luo J, Xue J, Yang H, Zhang S, Cao J (2014) Epigallocatechin-3-gallate (EGCG) protects skin cells from ionizing radiation via heme oxygenase-1 (HO-1) overexpression. J Radiat Res 55:1056-1065

Zhu W, Jia L, Chen G, Zhao H, Sun X, Meng X, Zhao X, Xing L, Yu J, Zheng M (2016) Epigallocatechin-3-gallate ameliorates radiation-induced acute skin damage in breast cancer patients undergoing adjuvant radiotherapy. Oncotarget 7:48607-48613 